
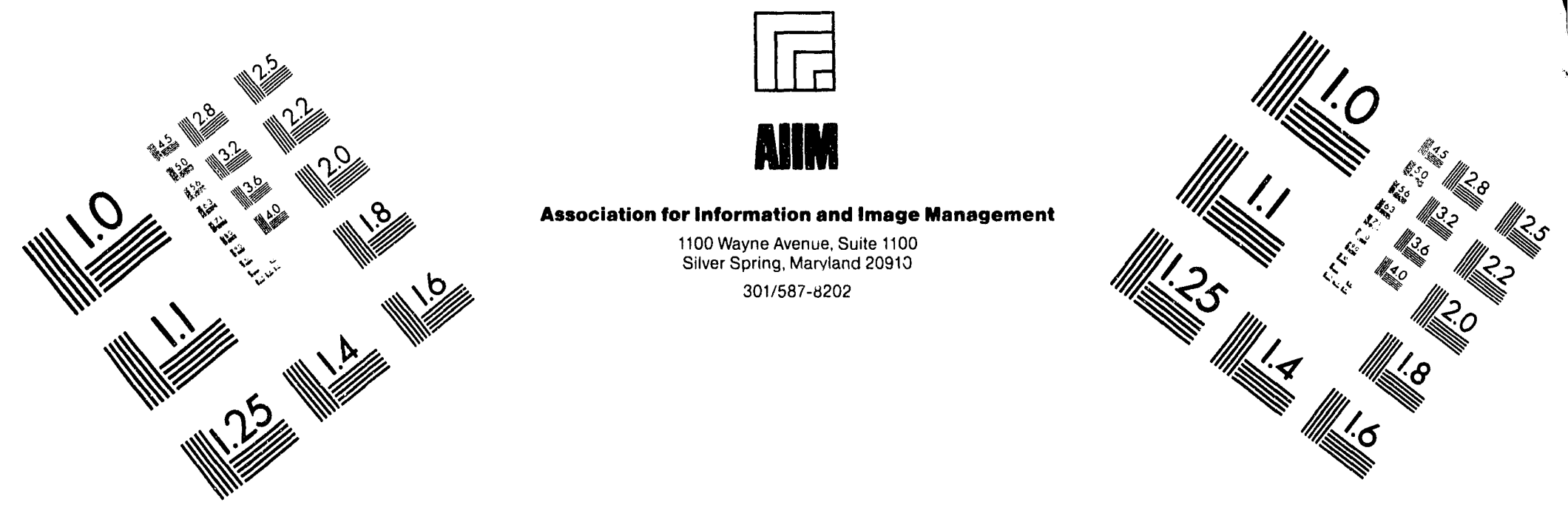

\title{
Centimeter
}

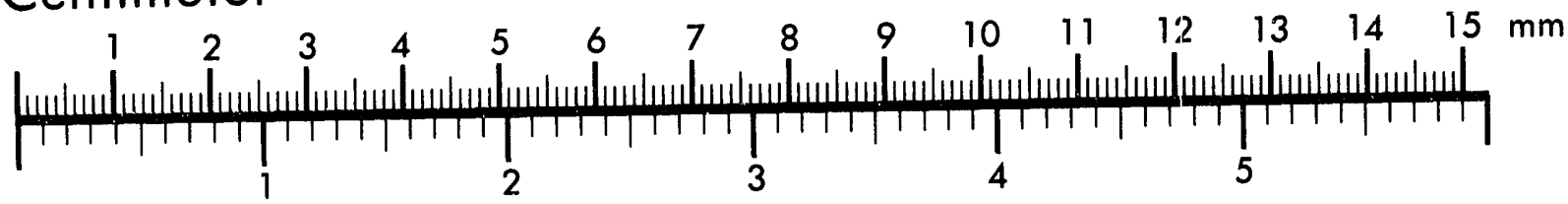
Inches
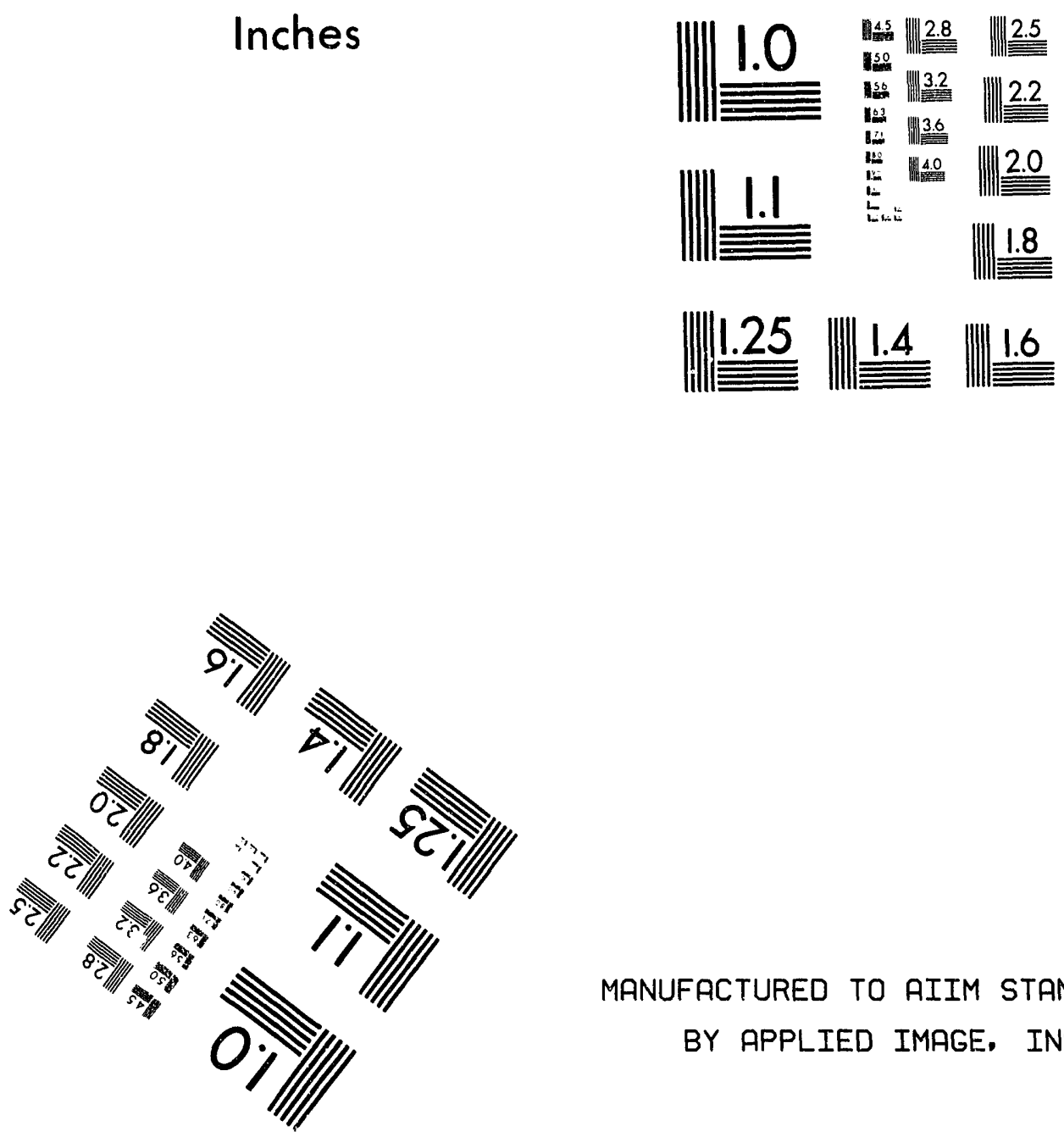

MANUFACTURED TO AIIM STANDARDS

BY APPLIED IMAGE, INC.

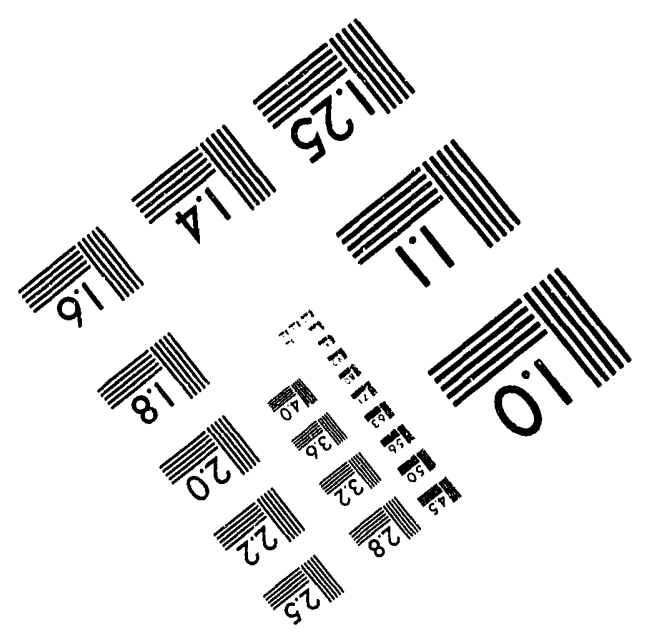



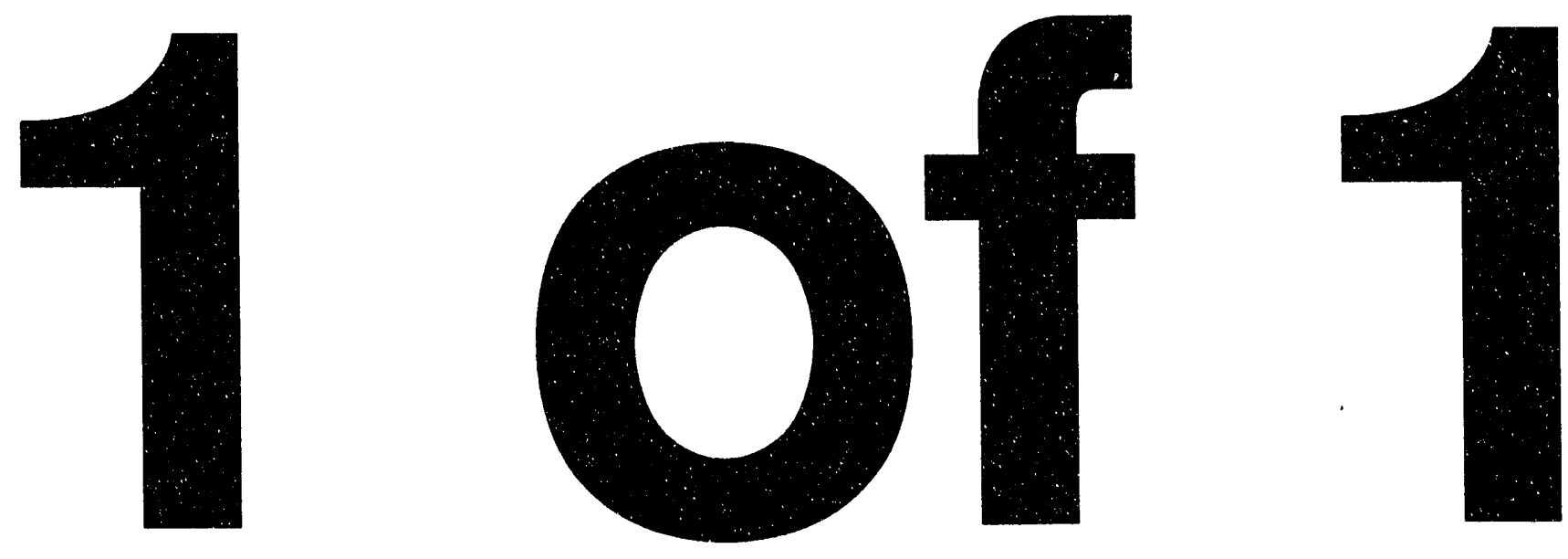


\title{
DOE/CH/10324 - T/9
}

\section{Southern State Radiological Emergency Preparedness and Response Agencies}

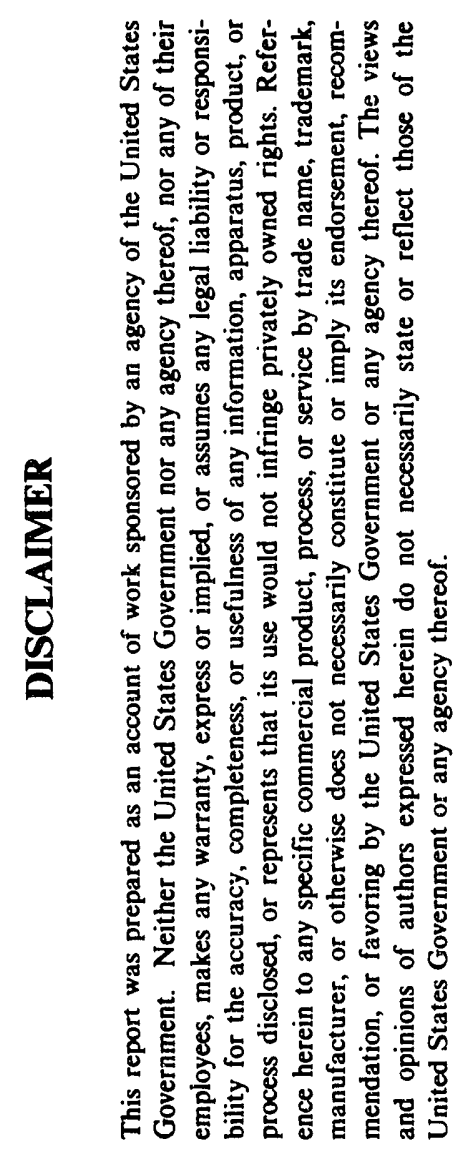

\author{
Southern States Energy Board \\ Norcross, Georgia
}

Prepared for U.S. Department of Energy under

Cooperative Agreement DE-FC02\%-87CH10324

November 1988 


\section{TABLE OF CONTENTS}

Page

Introduction

$\begin{array}{ll}\text { Al abama } & 3\end{array}$

$\begin{array}{lr}\text { Arkansas } & 7\end{array}$

Florida $\quad 11$

$\begin{array}{ll}\text { Georgia } & 15\end{array}$

Kentucky

$\begin{array}{ll}\text { Louisiana } & 25\end{array}$

$\begin{array}{ll}\text { Maryland } & 27\end{array}$

$\begin{array}{ll}\text { Mississippi } & 31\end{array}$

$\begin{array}{ll}\text { Missouri } & 35\end{array}$

$\begin{array}{ll}\text { North Carolina } & 37\end{array}$

$\begin{array}{ll}\text { Oklahoma } & 43\end{array}$

$\begin{array}{lr}\text { South Carolina } & 45\end{array}$

$\begin{array}{lr}\text { Tennessee } & 49\end{array}$

Texas

$\begin{array}{ll}\text { Virginia } & 57\end{array}$

West Virginia $\quad 59$ 
The responsibility for initially responding to a transportation accident generally falls to the state, tribal and local governments. In addition, the local government must determine the action required to prevent further damage to life or property. The federal government provides support to these governments upon request through planning guidance, training and technical and financial assistance.

General federal agency responsibilities for radiological emergency assistance are set forth in Part 351, Title 44 of the Code of Federal Regulations, "Radiological Emergency Planning and Preparedness." The Federal Radiological Emergency Response Plan (Federal Register, Vol. 50, No. 217, pp. 46542-46570, November 8, 1985) further describes the authorities and responsibilities of the following 12 federal agencies:

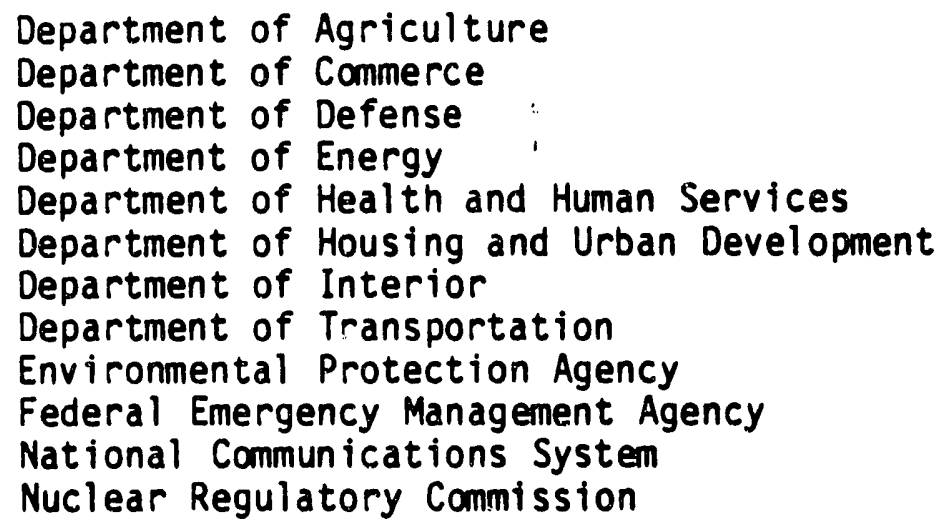

The Federal Emergency Management Agency (FEMA) has the primary federal planning and guidance role in radiological emergency response. In August 1988 the agency issued for review a draft revision of FEMA-REP-5, Guidance for Developing State and Local Emergency Response Plans and Preparedness for Transportation Accidents. Since there are no federal laws or regulations requiring state, tribal and Tocal governments to develop radioactive waste transportation emergency plans, use of the FEMA guidance is voluntary.

State, tribal and local requests for federal assistance may be received in a number of ways. The initial notification point depends on the organization making the request and the type of assistance requested. For example, state emergency management or radiological health organizations requesting radiological monitoring assistance are cognizant of the capabilities of the Department of Energy and would call the appropriate Regional Coordinating Office directly. The Department of Energy would be responsible for notifying other federal agencies that would participate in radiological monitoring efforts. Requests for other types of assistance, such as communications and logistics, would be coordinated by FEMA. 
The Department of Energy provides emergency response advice and assistance upon request from licensees; federal, state, tribal and local agencies; private organizations; and individuals involved in or cognizant of an incident believed to involve source, byproduct, special nuclear material or other ionizing radiation sources. The initial response is coordinated by one of the eight Regional Coordinating Offices.

When requested, the Environmental Protection Agency (EPA) assists state and local governments with radiological emergency response by providing environmental monitoring, accident assessment and protective action guidance. In the event the federal government is requested to assist in offsite monitoring efforts, the EPA would assume responsibility (from the Department of Energy, who is responsible for initial offsite radiological monitoring efforts) for intermediate and long-term offsite monitoring activities.

The federal government is heavily involved in training all levels of emergency responders. Programs are conducted by DOE, FEMA, the Department of Transportation and their contractors. Target audiences include first responders, emergency planners, decision makers in emergency operations centers and technical personnel involved in accident assessment.

This State Radiological Emergency Preparedness and Einergency Response Agency Report provides information on the state agencies assigned to radioactive materials transportation incidents in 16 Southern States Energy Board member states. For each, the report lists the agencies with primary authority for preparedness and response, their responsibilities and personnel within the agencies who can offer additional information on their radioactive materials transportation programs.

The report also lists each state's emergency team members and its laboratory and analytical capabilities. Finally, the governor's designee for receiving advance notification of high-level radioactive materials and spent fuel shipments under 10 CFR Parts 71 and 73 of the U.S. Nuclear Regulatory Commission's regulations is listed for each state. Part 71 requires prenotification for large quantity radioactive waste shipments. Part 73 addresses prenotification for spent nuclear reactor fuel shipments.

This information was compiled under a cooperative agreement with the U.S. Department of Energy (DE-FCO2-87CH10324) as part of the high-level radioactive waste transportation program. Since the personnel and equipanent data are subject to change, the Southern States Energy Board plans to provide for annual updates in future work performed under this or subsequant agreements. 


\section{ALABAMA}

GOVERNOR

The Hon. Guy Hunt (Term ends January 1991)

State Capitol

Montgomery, Alabama 36130

(205)261-7100

\section{EMERGENCY SERVICES}

The Alabama Emergency Management Agency (AEMA) is responsible for the preparation and implementation of a comprehensive emergency operations plan to cope with emergencies and disasters. Coordination of emergencies are conducted through the State Emergency Operations Center and/or a mobile command post. In the area of radiological emergency response, AEMA works jointly with the Department of Health (Bureau of Radiological Health) and other agencies to coordinate federal, state and local response activities and a public information program.

J. Danny Cooper, Director

Al abama Emergency Management Agency

520 South Court Street

Montgomery, Al abama 36130

(205)834-1375 (Duty hours)

(205)261-4378 (Non-duty hours)

\section{HEALTH SERVICES}

The Department of Public Health is the idministrative agency for the State Board of Health, which manages the Agreenent State Program and is the designated radiation control agency. The bozrd is authorized to issue rules and regulations on radioactive material transportation and may inspect waste shipments. The State Health Officer is the director of the Department of Public Health and also serves as head of the State Board of Health. As head of the state radiation control agency, the State Health Officer is responsible for issuing orders, declaring emergencies and directing protective actions.

Operational responsibilities include determination of protective actions and performance of off-site radiation monitoring and control activities. The department will handle all technical aspects of radiation in an emergency and will provide medical support to local governments.

Claude Earl Fox, M.D., M.P.H.

State Health Officer

Department of Public Health

Montgomery, Al abama 36130

(205) $261-5052$ 
DESIGNEE FOR ADVANCE NOTIFICATION OF SHIPMENTS

Col. Thomas H. Wells

Director

Alabama Department of Public Safety

P.0. Box 1511

Montgomery, Alabama 36192

(205)261-4378

RADIOLOGICAL EMERGENCY ASSISTANCE CONTACTS

State Police

(205)261-4378

Al abama State Board of Health

(205)261-5315 (8AM - 5PM)

Radiological Health Branch

State Office Building, Room 510

Montgomery, Al abama 36130-1701

Emergency Team Members

Name

Title

Godwin, Aubrey V.

Director, Radiological Health Branch

Whatley, Kirksey E.

Section Chief, Radioactive Material Licensing

Hannah, B.0.

Section Chief, Environmental Monitoring \& Emergency

Plans

If above unavailable call ................... 205)261-4378 and ask operator to page No. 971

LABORATORY AND ANALYTICAL PROGRAMS

Type of Sample Type of Analysis

Major Equipment

Air

Gross Beta

Canberra Alpha-Beta 2201

Fish

Garma Analysis

Canberra Series 90

Int. Germanium

Low-Level Gamma

Canberra Series 90

Int. Germanium

Milk

Strontium - 89, 90

Canberra Series 90

Gamma Analysis

lodine - 131

Int. Germanium

Barium - 140

Cesium - 137

Potassium - 40

Canberra Alpha-Beta 
Soil

Vegetation

Water
Gamma Analysis

Gamma Analysis

Gamma Spectrum

Gross Beta
Canberra Series 90

Int. Germanium

Canberra Series 90

Int. Germanium

Canberra Series 90

Int. Germanium

Canberra Alpha-Beta

In addition, a portable Canberra Series 10 is available. 


\section{ARKANSAS}

GOVERNOR

The Hon. Bill Clinton (Term ends January 1991)

State Capitol

Little Rock, Arkansas 72201

(501) $371-2345$

\section{EMERGENCY SERVICES}

The Office of Emergency Services is charged with coordinating emergency relief and the prevention of disasters. The director is appointed by the governor, and the office maintains a state disaster plan.

The State Emergency Operations Center, located south of Conway, Arkansas, is operated at all times. In the event of an emergency, the state is divided into four operational areas with an area coordinator for each. The area coordinators serve a liaison function among the office director, area planning councils and county and municipal governments.

Jack DuBose, Acting Director

Office of Emergency Services

P.0. Box 758

Conway, Arkansas 72032

(501)329-5601

\section{HEALTH SERYICES}

In an emergency the Department of Health has primary responsibility for health and medical assistance; water and sanitation inspection; chemical hazard response; recovery, identification and disposa! of fatalities; vector control; radiological incident response; and maintenance of state-owned radiological equipment. In the specific ir ea of radiological incident response, the Department of Health is in charge of technical evaluation and assessment and the issuance of guidelines and directives for protective actions.

M. Joycelyn Elders, M.D., Director

Department of Health

4815 West Markhan Street

Little Rock, Arkansas 72201

(501)661-2111 
DESIGNEE FOR ADVANCE NOTIFICATION OF SHIPMENTS

Greta J. Dicus

Director

Division of Radiation Control and Emergency Management Programs

Arkansas Department of Health

4815 West Markham Street

Little Rock, Arkansas 72201

(501) $661-2136$

RADIOLOGICAL EMERGENCY ASSISTANCE CONTACTS

office of Emergency Services

Arkansas Department of Health

Division of Radiation Control

\& Emergency Management

4815 West Markham

Little Rock, Arkansas 72201

Emergency Team Members

Name

Title

Dicus, Greta J.

Bevill, Bernard

Giel, James

Sands, Jimmy L.

Elders, Joycelyn, M.D. State Health Officer

In addition to the above individuals, the following positions make up the Emergency Response Team composition:

\author{
(501)374-1201 (24 hours) \\ (501)661-2136 (24 Hours)
}

Director, Div. of Radiation Control \& Emergency Management

Supervisor, Nuclear and Enviromental Safety Section

Supervisor, Radioactive Materials Section

Supervisor, X-Ray Section

Health Physicists

State OES Liaison

Administrative/Clerical Support

9 individuals

1 individual

7 individuals

Radiological Defense Officer

1 individual

Laboratory Technicians

2 individuals

Logistical Support

2 individuals

Public Information

4 individuals

Radiochemistry

Communication Specialists

2 individuals

6 individuals

Additional logistical and radiation monitoring support is available from other Health Department divisions. 
LABORATORY AND ANALYTICAL PRUGRAMS

\begin{tabular}{|c|c|c|}
\hline Type of Sample & Type of Analysis & Major Equipment \\
\hline Air & $\begin{array}{l}\text { Gross Alpha } \\
\text { Gross Beta } \\
\text { lodine - } 131 \text { and } \\
\text { other gamma emitters }\end{array}$ & $\begin{array}{l}\text { Packard Tri-Carb 2000CA liquid } \\
\text { scintillation analyzer with } \\
\text { printout. }\end{array}$ \\
\hline $\begin{array}{l}\text { Charcoal Filter } \\
\text { Fish }\end{array}$ & $\begin{array}{l}\text { Gamma Analysis } \\
\text { Gamma Analysis }\end{array}$ & $\begin{array}{l}\text { Nuclear-Chicago Model } 8700 \\
\text { Internal Proportional Counter } \\
\text { with printout. Canberra Model } \\
2201 \text {. }\end{array}$ \\
\hline Milk & $\begin{array}{l}\text { Strontium- } 89,90 \\
\text { Gamma Anal ys is } \\
\text { Iodine }-131 \\
\text { Barium-1 } 40 \\
\text { Cesium-137 } \\
\text { Potassium-40 }\end{array}$ & $\begin{array}{l}\text { Transnuclear Low-Background Beta } \\
\text { Counter Canberra Model } 2200 . \\
1 \text { - Gamma Spectroscopy System } \\
\text { Consisting of: }\end{array}$ \\
\hline $\begin{array}{l}\text { Soil and Silt } \\
\text { Vegetation }\end{array}$ & $\begin{array}{l}\text { Gamma Analysis } \\
\text { Gamma Analysis }\end{array}$ & $\begin{array}{c}1 \text { - Multichannel Analyzer } \\
\text { (Nuclear Data 990) }\end{array}$ \\
\hline Water & $\begin{array}{l}\text { Gross Alpha } \\
\text { Gross Beta } \\
\text { Tritium } \\
\text { Gamma Analysis } \\
\text { Radium-226,228 } \\
\text { Strontium- } 89,90 \\
\text { Uranium }\end{array}$ & $\begin{array}{l}1 \text { - } 4 \times 4 \text { inch sodium iodide } \\
\text { (TI) detector (Harshaw) } \\
\text { with shielding. } \\
1 \text { - Canberra Geli detector } \\
\text { and associated software } \\
\text { with shielding. }\end{array}$ \\
\hline
\end{tabular}

Wipe Test

Gross Alpha

Gross Beta

Technitium-99

Nickel

Tritium

Field Equipment (Average Inventory)

14 Ludlum Model 3 Survey Meters with:

10 Ludlum Model 44-2 Gamma Scintillators

12 Ludlum Model 44-9 Pancake Probes

9 Ludlum Model 43-5 Alpha Scintillators

14 Ludlum Model 44-6 Thin Wall Gamma Probes

1 Ludlum Model 42-4 Thermal Neutron Probe

6 Ludlum Model 17 Ion Chambers

1 Ludlum Model 18 Analyzer with:

a. Neutron Ball

b. Ca7 Alpha Probe

2 Ludlum Model 12S Micro R Meters

1 Eberline PRM-6 Survey Meter

3 Eberline ESP-1 Survey Meters

2 Keithley Instruments Model 36150 Ion Chambers 
7 Texas Nuclear Corp./Warning to Labs Model 2592 Ion Chambers

12 Victoreen Model 06-502 "Chirpers"

11 Extex Model 415A "Chirpers"

9 MRH Ion Chambers

3 Reuter-Stokes Model RS-111 Pressurized Ion Chambers

1 Canberra Series 10 Portable MCA with 2" $\times 2 " \mathrm{NaI}$ (TZ) probe

1 Eberline MS-3 Scaler with GM Pancake Probe

1 Harsha Nuclear Systems 2000P TLD System with Calcium Fluoride Dysprosium TLD bulbs

1 Ludlum Model 2218 Dual Channel Analyzer with 2" $\times 2 "$ NaI (TL) Gamma Scintillator

1 Everline Model PNC-1 Neutron Detector

1 Narda Microwave detector

2 RadeCo Model HD-28B Air Samplers

6 RadeCo Model H-809C Air Samplers

6 Staplex Model T71A Air Samplers

5 vehicles equipped with other miscellaneous emergency response equipment and 2 communication systems - Arkansas Department of Health radios

- Arkansas Department of Emergency Services radios

1 Mobile Emergency Operations Center (semi-trailer)

12 Handheld Portable radios (mi scellaneous manufacturers)

1 Victoreen Model 2810-1 TLD Reader with TLD bulbs

Radiological Defense Equipment

The following radiological defense equipment is managed by the Radiological Defense Program within the Arkansas Department of Health. The equipment is in stock storage at the department or is in place in most counties under the jurisdiction of the County Emergency Services Coordinator.

Survey Meters: Victoreen Model CDV-700 Victoreen Model CDV-715

Victoreen Model CDV-720

Dosimeters: Victoreen Model COV 138

Victoreen Model CDV 730

Victoreen Model CDV 740

Victoreen Model CDV 742

Victoreer: Model CDV 750 (Chargers) 
FLORIDA

GOVERNOR

The Hon. Bob Martinez (Term ends January 1991)

State Capitol

Tallahassee, Florida 32301

(904) 488-4441

\section{EMERGENCY SERVICES}

The Division of Emergency Management in the Department of Community Affairs is responsible for preparing and implementing a comprehensive program to meet disasters and emergencies. In the area of radiological emergency response, the division maintains a plan for nuclear power plant emergencies; provides assistance in the preparation of local plans; coordinates federal, state and local response activities; activates a state emergency operations center; and manages a public information program.

Gordon Guthrie, Director

Division of Emergency Management

Department of Community Affairs

2740 Centerview Drive

Tallahassee, florida 32399

(904)488-1900

\section{HEALTH SERVICES}

The Florida Radiation Protection Act designates the Department of Health and Rehabilitative Services as the lead agency for radiation safety. The department also administers the Agreement State Program. The act was amended in 1984 to require the department to protect the environment, in addition to the public, from harmful radiation effects. Hence, the department al so undertakes environmental surveillance activities.

Charles S. Mahan, M.D.

Deputy Assistant Secretary for Health

Department of Health and Rehabilitative Services

1317 Winewood Blvd.

Tallahassee, Florida 32301

(904)487-2705

\section{DESIGNEE FOR ADVANCE NOTIFICATION OF SHIPMENTS}

Harlan Keaton

Office of Radiation Control

Florida Department of Health and Rehabilitative Services

P.0. Box 15490

Orlando, Florida 32858

(407)297-2095 
RADIOLOGICAL EMERGENCY ASSISTANCE CONTACTS

Office of Radiation Control

(904)487-1004

Department of Health and

Rehabilitative Services

1317 Winewood Boulevard

Tallahassee, Florida 32301

Orlando Office

(407)297-2095

Emergency Team Members

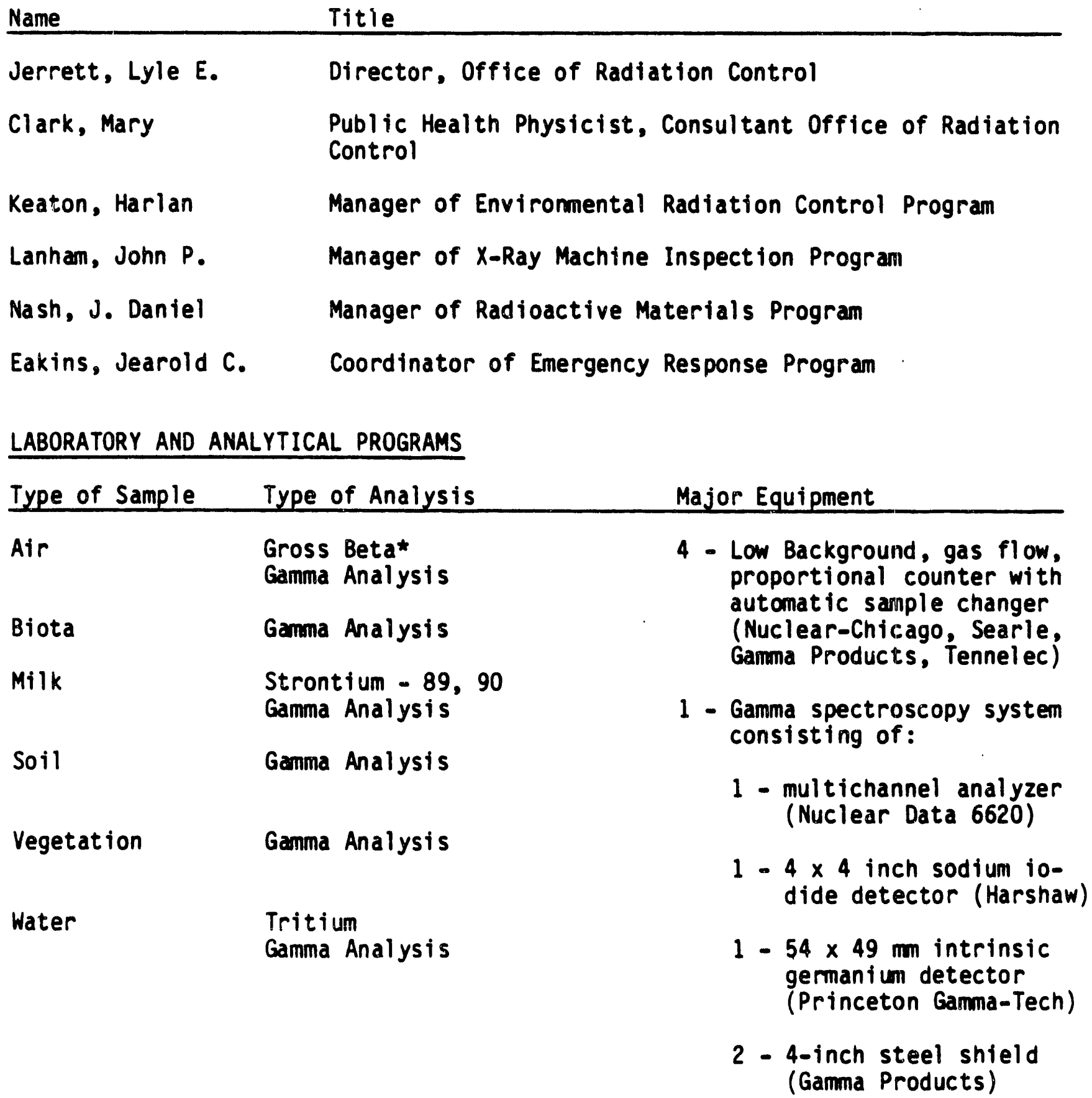


1 - Liquid scintillation spectrometer (Packard Tri-Carb 3255)

1 - Automatically controlled electric furnace (Lucifer)

1 - TLD reader system (Harshaw 2000)

* Gamma analysis when gross is greater than $1 p C i: m^{3}$

Mobile Laboratory

"Winnebago" 27 ' complete with:

a. A.C. Generator (6.5kw)

b. Wind speed and direction indicator system

c. Gamma spectroscopy system consisting of:

1. Hewlett-Packard Model $9825 \mathrm{~S}$ desktop computer

2. Hewlett-Packard printer and plotter

3. Intrinsic Germanium Detector 24\%

4. Tracor Northern 4000 channel analyzer

d. Nuclear Measurements Corp. gas flow proportional counter

e. Victoreen model 2800 TLD reader

f. Hi-Vol air samplers 110VAC, (8)

g. Low-Vol air samplers 12VDC, (4)

h. Ludlum 12-S Micro-R meters, 0-3,000 UR/hr. (8)

i. Eberline E-140 Ratemeters with G-M probes, 0-70,000 cpm (2)

j. Eberline PRM-5-3 Ratemeters with alpha scintillation probes and G-M probes, $0-500,000 \mathrm{cPm}$ (2)

k. Pressurized ion chamber, $0-500 \mathrm{uR} / \mathrm{hr}$ (2)

1. COV-700 G.M. instruments with thin end window and side window probes, $0-30,000 \mathrm{cpm}(4)$

m. COV-715 ion chambers, $0-500 \mathrm{R} / \mathrm{hr}$ (10)

$\mathrm{n}$. Victoreen Panoramic ion chambers, $0-1000 \mathrm{R} / \mathrm{hr}$ (2)

0. Ludlum 2200 , portable single channel analyzer, 0-500,000 cpm, with sodium iodide detectors (4)

p. Aerial gamma survey system with 7" plastic scintillator, 0-500,000 cpm 
q. Self-reading pocket dosimeters with chargers:

$0-200 \mathrm{mr}$ (30)

$0-20 R(22)$

$0-200 R(20)$

$0-5 R(15)$

r. Ludlum Model 2 Ratemeters with pancake probes, 0-50,000 cpm (2)

5. Ludlum Model 2220 Ratemeter/Scaler with 2" NaI detectoi', 0-500,000 cpm (1) 
GEORGIA

GOVERNOR

The Hon. Joe Frank Harris (Term ends January 1991)

State Capitol

Atlanta, Georgia 30334

(404)656-1776

\section{EMERGENCY SERVICES}

The Emergency Management Agency of the Department of Defense prepares and implements the state's emergency management program. The executive director is authorized to make rules or regulations subject to the governor's approval.

In a radiological emergency, the Department of Defense provides for communication through the state emergency operations center and/or the mobile operations center. It will also perform radiological monitoring, activate evacuation procedures, assist in response personnel and equipment transportation and coordinate a public information effort.

Mr. Billy J. Clack, Executive Director

Georgia Emergency Management Agency

Department of Defense

P.0. Box 18055

Atlanta, Georgia 30316

(404)624-7000

In a radiological transportation emergency the Georgia Department of Natural Resources (DNR) Environmental Protection Division (EPD) is notified through the Emeryency Operations Center (EOC) operated by DNR Law Enforcement. This center is manned twenty-four hours a day. On receipt of an emergency call reporting a radiological transportation emergency; the EOC radio operator contacts the Emergency Response Team Duty Officer and the state's Radiological Emergency Coordinator (REC). The REC evaluates the situation and makes decisions on the level and extent of emergency response. The REC may call on the Georgia Emergency Management Agency of the Department of Defense for additional resources beyond those of the Emergency Response Team. The Emergency Response Team would be activated at the request of the REC. The team would perform radiological monitoring and situation evaluation as well as technical assistance to local emergency authorities.

J. Leonard Ledbetter

Commissioner

Department of Natural Resources

Floyd Towers East

205 Butler Street, SE

Atlanta, Georgia 30334

(404)656-3500 
James C. Hardeman, Jr., Radiological Emergency Coordinator

Georgia Department of Natural Resources

Environmental Protection Division

Floyd Tower East 1166

205 Butler Street, SE

Atlanta, Georgia 30334

$(404) 656-6905$

\section{HEALTH SERVICES}

Georgia's radiation control legislation gives administrative authority to the Department of Human Resources for the Agreement State Program. The department has exclusive authority to license medical uses of radioactive material and is authorized to license all other uses of radioactive materials. Prior to issuing a new or renewal license the department must obtain the concurrence of the Environmental Protection Division of the Department of Natural Resources for those license applicants who have a potential for release of radioactive material to the environment. The lead responsibility for radiological emergency response bel ongs to the Department of Natural Resources. The Department of Human Resources provides technical assistance upon the request of the Department of Natural Resources.

James G. Ledbetter

Commissioner

Department of Human Resources

47 Trinity Ave., SH

Atlanta, Georgia 30334

(404)656-5680

DESIGNEE FOR ADVANCE NOTIFICATION OF SHIPMENTS

Tom Doyal

Director

Transportation Division

Georgia Public Service Commission

1007 Virginia Avenue

Hapeville, Georgia 30354

(404) 761-2229

RADIOLOGICAL EMERGENCY ASSISTANCE CONTACTS

Emergency Operations Center

$1-800-241-4113$ (24 Hours)

Georgia Emergency Management Agency

(404)624-7000 (24 Hours)

Department of Natural Resources

(404)656-4300 (24 Hours)

Environmental Protection Division

(404)656-6905 (8AM - 4:30PM)

Floyd Tower East

205 Butler Street, SE

Atlanta, Georgia 30334 


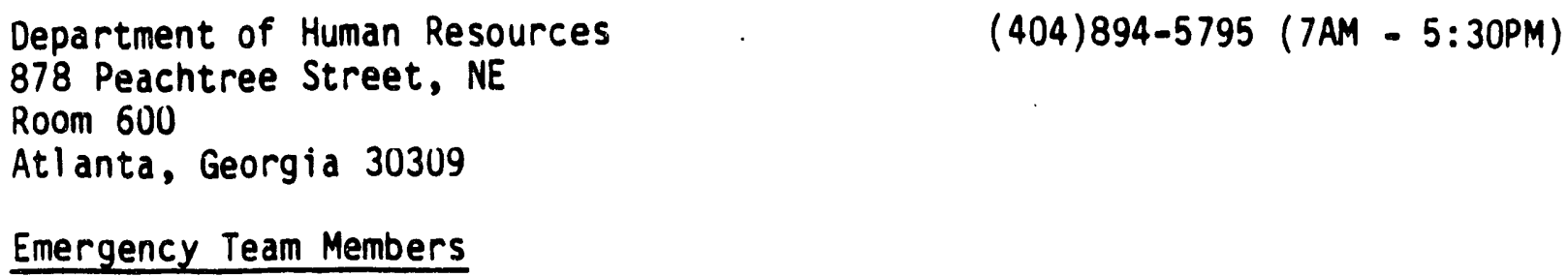


Milk

Soil

Stream/Harbor Sediment

Vegetation
Gamma Spectrum

Tritium

Strontium

Radioiodine (I-131)

Gamma Spectrum

RadioStrontium

Garma Spectrum

Gamma Spectrum

RadioStrontium

Tritium
Alpha Scintillation

Harshaw TLD-2000 Reader (LiF and $\mathrm{CaF}$ )

Water

Gross Beta, Gross Gamma,

Tritium, Strontium,

Radioiodine (I-131)

Routine laboratory analysis of environmental samples are conducted in a lowlevel fixed environmental radiation laboratory. A summary of the instrumentation resources available is as follows:

Three - Ge(Li) Type Detectors

One - NaI Type Detector

One - 64000 Channel Multi-Channel Analyzer w/DEC-Micro-11-Computer

One - Spectrofluorometer

Two - Automatic Gas Proportional Alpha/Beta Analyzers

One - Liquid Scintillation Analyzer

Six - Radon Scintillation Counters

One - TLD Annealer and Reader

One - Networked Computer System

Two - Pressurized Ionization Chambers

One - Beta/Gamma Anticoincidence System

One - Alpha Spectrometer

DNR Emergency Vehicles

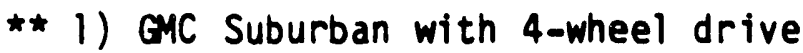

** 2) Mobile Laboratory equipped with the following:

a) MCA - HpGe(Li) with IBM XT computer for dose projection and gamma spectrum analysis

b) Liquid Scintillation System

c) Alpha/Beta Counting System (Gamma Proailcts)

d) TLD Reader

e) Air Samplers (battery, gasoline, and eiectrical operated)

f) Survey meters (ion, Alpha, Beta, Mirr J-R, Geiger and Neutron detectors)

g) Dosimetry systems (digital, pocket, 'stc.)

h) Protective equipment

i) Portable generator

j) Tritium Sniffer 
3) GMC 20 foot van equipped with radio communication capability to Civil Defense, DNR/EPD and other state agencies

4) Boating capability for surveying and water sampling as a backup for emergency response

\# Indicates extensive radio communication capability (i.e. Civil Defense, Public Safety, local sheriffs, DNR, etc.) 


\section{KENTUCXY}

GOVERNOR

The Hon. Wallace G. Wilkinson (Term ends December 1991)

State Capitol

Frankfort, Kentucky 40601

(502) $564-2611$

\section{EMERGENCY SERVICES}

The Division of Disaster and Emergency Services in the Department of Military Affairs is headed by the Adjutant General of the Commonwealth of Kentucky. The division is the lead state agency for response planning and coordination. The division's responsibilities include activation of the Emergency Operations Center and Emergency Communications Center, coordination of planning and response with adjacent states, public information dissemination and radiological protection coordination.

Col. James H. (Mike) Molloy, Executive Director

Division of Disaster and Emergency Services

Boone National Guard Center

Frankfort, Kentucky 40601

(502) $564-8680$

\section{HEALTH SERVICES}

The Cabinet for Human Resources administers the Agreement State Program and monitors sites where radioactive materials exist. Within the cabinet, the Radiation Control Branch has primary responsibility for response to peacetime radiological incidents.

Harry J. Cowherd, M.D., Secretary

Cabinet for Human Resources

275 East Main Street

Frankfort, Kentucky 40621

(502) 564-7130

DESIGNEE FOR ADVANCE NOTIFICATION OF SHIPMENTS

Donald R. Hughes

Manager

Radiation Control

Department for Health Services

Cabinet for Human Resources

275 East Main Street

Frankfort, Kentucky 40621

(502) 564-3700 
RADIOLOGICAL EMERGENCY ASSISTANCE CONTACTS

\section{State Police}

Division of Disaster and Emergency Services

Radiation Control Branch

Department for Health Services

Cabinet for Human Resources

275 East Main Street

Frankfort, Kentucky 40621

Emergency Team Members
(502)564-3579

(502)564-7815 (Pager Service)

(502)564-3700 (8AM - 4:30PM)

Name

Title

Hughes, Donald R.

Manager, Radiation Control

Mays, Mark L.

Supervisor, Radioactive Materials and Environmental

Monitoring Section

Jeffs, Vicki

Senior Radiation Physicist

Imes, Kevin $M$.

Radiation Physicist

Volpe, John, Ph.D.

Chief Chemist

LABORATORY AND ANALYTICAL PROGRAMS

Type of Sample

Air

Biota

Milk or

Water

Soil

Water
Type of Analysis

Gross Alpha, beta

or Gamma analysis/

soil, water, air, biota, milk, etc., and specific analysis for strontium, radium, tritium and gamma emitters
Major Equipment

100, Sample capacity, automated low background alpha and beta counting instrument.

Chemistry laboratory (wet chemistry ion exchange system, muffle furnace drying ovens, radiochemistry hood, etc.)

200, Sample capacity, automated 3 channel liquid scintillation counting system.

Computer based 6600 Nuclear Data System with portable Nuclear Data 66 multichannel analyzer and portable Germanium detector for field analysis of gamma emitters. 
One Germanium and one Geli detector available with calibration for the following geometrics:

200 gram dry soil/silt sample ( 200 mesh)

3.0 liter water sample

3.0 liter milk sample

20 milliliter ylass liquid scintillation vial

140 millimeter charcoal filter

500 milliliter water sample 
LOUISIANA

GOVERNOR

The Hon. Buddy Roemer (Term ends March 1992)

State Capitol

Baton Rouge, Louisiana 70804

(504) 342-7015

\section{EMERGENCY SERVICES}

The Office of Emergency Services coordinates and controls emergency operations as directed by the governor. If warranted by the emergency, the office activates the state's emergency operations and communications centers. It coordinates the nontechnical response to a radiological incident and assists parish governments with their protective response planning.

Tom Creaghan, Assistant Secretary

Office of Emergency Preparedness

Department of Public Safety and Corrections

P.0. Box 66536

Baton Rouge, Louisiana 70896

(504)342-5470

\section{HEALTH SERVICES}

The Office of Air Quality and Nuclear Energy administers the state's radiation control law and the Agreement State Program. The office is headed hy an assistant secretary, who is appointed by the governor with the consent of the Senate.

The Nuclear Energy Division, Office of Air Quaitity and Nuclear Energy, provides technical guidance and assistance to state and parish governments in the areas of accident assessment, monitoring, sampling and decontamination. The division also conducts education programs to inform the media and public of radiation, its hazards and appropriate protective measures and provides training to emergency response personnel, both state and local.

Mike D. McDaniel, Ph.D., Assistant Secretary

Office of Air Quality and Nuclear Energy

Department of Environmental Quality

P.0. Box 44096

Baton Rouge, Loutsiana 70804

DESIGNEE FOR ADVANCE NOTIFICATION OF SHIPMENTS

Col. Wiley D. McCormick

Head

Louisiana State Police

P.0. Box 66614

Baton Rouge, Louisiana 70896

(504) 925-6117 
RADIOLOGICAL EMERGENCY ASSISTANCE CONTACTS

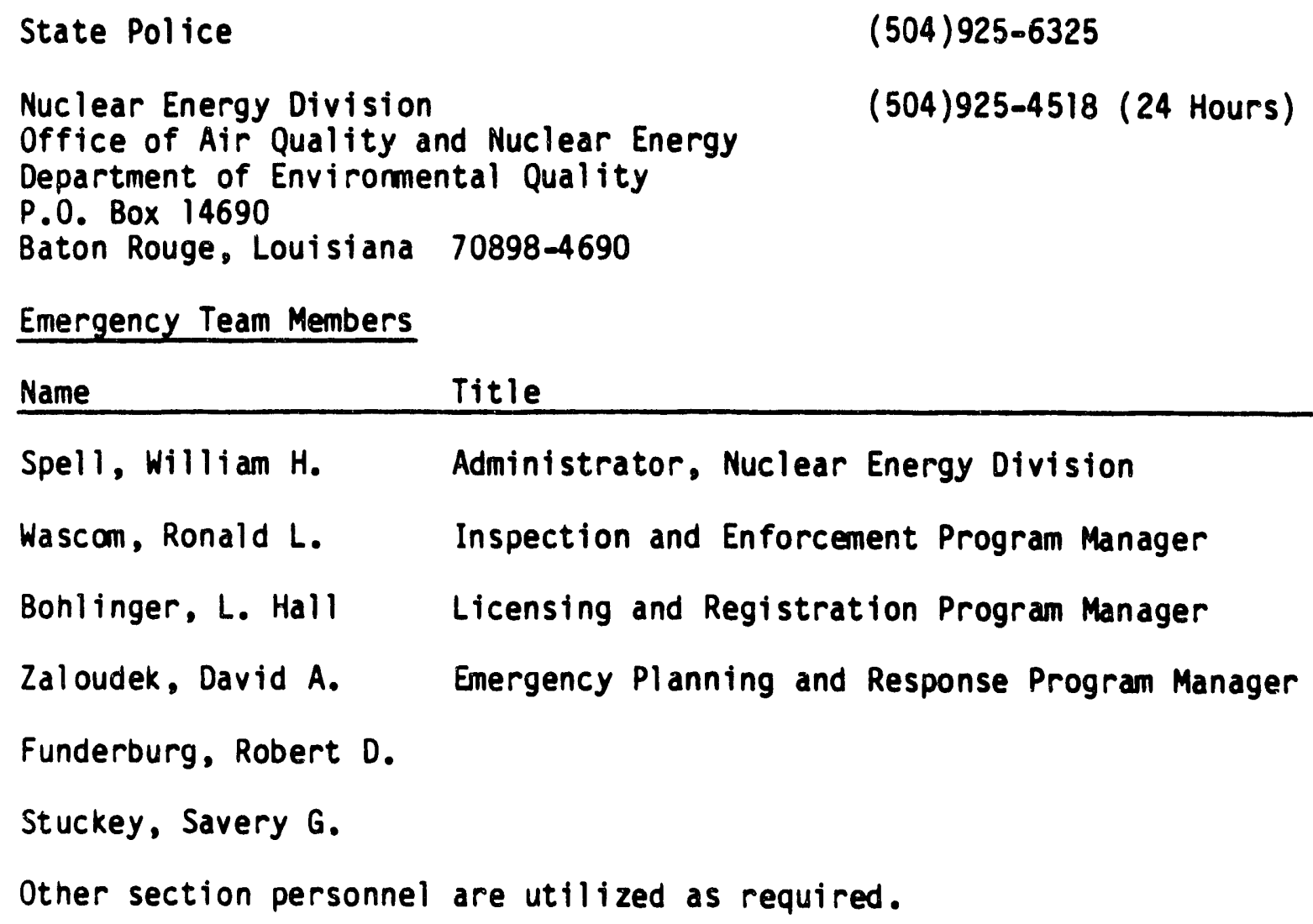

(504) $925-6325$

(504)925-4518 (24 Hours)

Ambient Gamma Environmental

TLD (Glass enclosed TLDs) Long Term Measurements

Water, Milk, Sedi- Gamma Spectroscopy ment, Vegetation, Air Filters, Fish, Swipes

Water, Air Filters, Gross Alpha/Gross Beta \& Swi pes Gross Gamma

Water Liquid Scintillation 
MARYLAND

GOVERNOR

The Hon. Donald Schaefer (Term ends January 1991)

State Capitol

Annapol is, Maryl and 21404

(301)269-3591

\section{EMERGENCY SERVICES}

The Emergency Management and Civil Defense Agency, a division of the Department of Public Safety and Corrections, is responsible for preparing and implementing the state emergency management program. In response to a radiological incident, the agency will notify the appropriate federal, state and/or local technical responders. If necessary, the agency will activate the state emergency operations center to coordinate assistance to local jurisdictions.

Edward Murray, Director

Emergency Management and Civil Defense Agency

Sudbrook and Reisterstown Road

Pikesville, Maryl and 21208

(601)352-9100

\section{HEALTH SERVICES}

Maryland's general radiation safety law designates the Department of the Environment as the radiation control agency. It also administers the Agreement State Program. In the event of a radiological incident, the department will provide assistance to local responders and can activate the Accident Assessment Center and the Ingestion Pathway Center. If the situation warrants, the department will provide the state public information officer with information on the emergency.

Martin W. Walsh, Jr.

Secretary

Department of the Environment

201 West Preston Street

Baltimore, Maryland 21201

(301)333-3130

DESIGNEE FOR ADVANCE NOTIFICATION OF SHIPMENTS

Col . James $A$. Jones

Chief, Services Bureau

Maryland State Police

1201 Reisterstown Road

Pikesville, Maryland 21208

(301)486-3101 
RADIOLOGICAL EMERGENCY ASSISTANCE CONTACTS

State Police

Emergency Management and Civil Defense

Assistant Secretary for Operations

Maryland Department of the Environment

Center for Radiological Health

Maryland Department of the Environment

201 West Preston Street, 7th Floor Mailroom

Baltimore, Maryl and 21201

Emergency Team Members

Name

Title

Fletcher, Rol and G.

Administrator, Center for Radiological Health

Brisson, Richard J.

Assistant Administrator, Center for Radiological Health

Perzynski, Paul R.

Bonta, William K.

Trump, Carl E.

Flynn, Charles R.

Ferguson, Thomas D.

Chong, Yun $K$.

Owrutsky, Nathaniel A. Health Physicist III

Scheltema, Johannes L. Health Physicist III

Manley, Raymond E. Health Physicist III

Chaparala, Phani N. Health Physicist III

Jacobson, Alan D. Health Physicist III

Van Antwerp, Walter R. Health Physicist III

Rachuba, Leon J. Health Physicist II

Ball, Anne

Health Physicist II

Abell, Francis E.
(301)486-3,101 (24 Hour)

(301)486-4.422 (24 Hour)

(301) 225-652.3

(301) $333-3130$
Emergency Response Coordinator/ Public Health Radiation

Public Health Engineer VI

Public Health Radiation Specialist

Public Health Radiation Specialist

Public Health Radiation Specialist

Health Physicist III

Health Aide IV 
LABORATORY AND ANALYTICAL PROGRAMS

Type of Sample Type of Analysis

Air

Air

Bay water

Bay sediments

Milk

Oyster flesh

Vegetation
Iodine - 131

in filtered air

Hydrogen - 8: gamma

Beta, gamma emitters

in air particulates

Gamma emitters

Gamma emitters:

Strontium - 89,90

Gamma emitters

Gamma emitters
Major Equipment

1 Nuclear Data Pulse Height Analyzer (ND 9900) Genie Computer based P.H.A. System capable of operating 8 detectors simultaneously in either clock or live time.

3 Ortec HPGe Detectors (Coaxial) Approx. 2" $\times 2$ 2" crystals EFF: $13.7 \%, 16 \%$ and 25\%. RES: $1.8 \mathrm{KeV} 3 \mathrm{LN}-2$ Monitors on cryostats.

2 Harshaw NaI (TL) Detector (Integral). 3" crystals with requisite electronics.

Tennelec automatic alpha-beta 1 proportional planckett counting system. Auto sample change (100 samples) $5 \times 10-4 \mathrm{~g} / \mathrm{cm}^{2}$ window. Printer output.

1 Beckman Liquid Scintillation (LS-133). Auto sample changer (100 samples). Printer output and page formator. 


\section{MISSISSIPPI}

GOVERNOR

The Hon. Ray Mabus (Term ends January 1992)

State Capitol

Jackson, Mississippi 39205

(601) 359-3150

\section{EMERGENCY SERVICES}

The Emergency Management Agency prepares and implements a state program for emergency management. The agency also issues permits for radioactive waste transportation. The state's "Guidance for Radiological Transportation Emergencies" gives the agency a support role unless the emergency warrants the use of additional personnel, evacuations or activation of the Mississippi Natural Disaster Plan.

James E. Maher, Director

Mississippi Emergency Management Agency

P.0. Box 4501, Fondren Station

Jackson, Mississippi 39216

(601)352-9100

\section{HEALTH SERVICES}

The State Department of Health is the administrative agency for the Board of Health, which implements the state's Agreement State Program. According to the Mississippi Radioactive Waste Transportation Act of 1982, the Board of Health must develop regulations for transportation permits, fees, notice and emergency response. Emergency response involves technical supervision, site isolation, monitoring and records management.

Alton B. Cobb, M.D.

State Health Officer

State Department of Health

P.0. Box 1700

Jackson, Mississippi 39215-1700

(601)960-7634

\section{DESIGNEE FOR ADVANCE NOTIFICATION OF SHIPMENTS}

James E. Maher, Director

Mississippi Emergency Managenent Agency

P.0. Box 4501, Fondren Station

Jackson, Mississippi 39216

(601)352-9100 
RADIOLOGICAL EMERGENCY ASSISTANCE CONTACTS

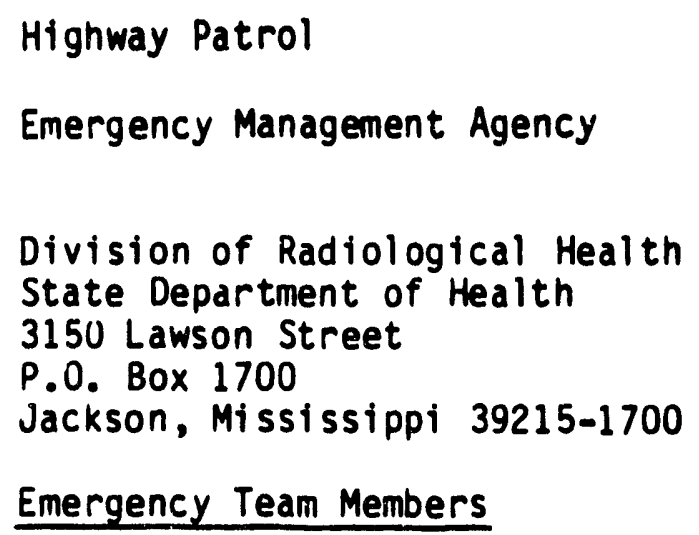

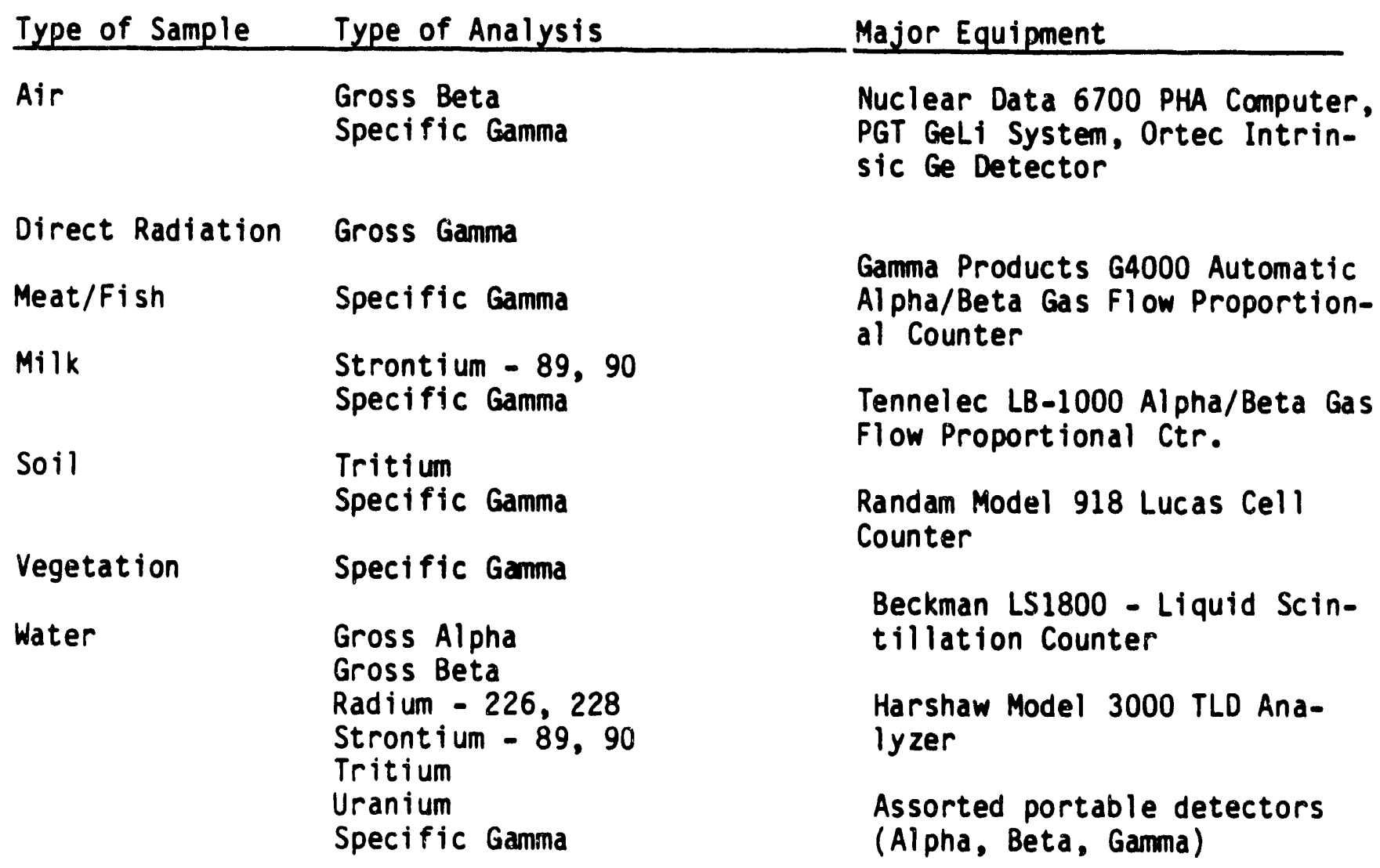

(601)987-1530 (24 Hours)

(601)352-9100 (24 Hours) 1-800-222-6362 (in Mississippi)

(601)354-6657/6670 (8AM - 5PM) 


\section{Emergency Vehicles}

1) Chevrolet Suburban 4-wheel drive with radio and trailering capability.

2) Dodge Ram van with radio.

3) Mobile Laboratory (trafler) equipped with the following:

a) Intrinsic Germanium detector with Nuclear Data ND66 and modem to main computer in Jackson (ND6700) and floppy disc backup

b) Liquid Scintillation System (Nuclear Enterprises)

c) Alpha/Beta Counting System (Canberra)

d) TLD Reader System (Harshaw 2000 Series)

e) Air Samplers (external battery)

f) Survey meters (ion, alpha, beta, gamma \& scintillometer)

g) Dosimetry equi pment (pocket with readers)

h) Protect ive equipment (Anti-C's, air packs, etc.)

i) Field chemistry supplies

j) Reuter-Stokes RSS-111 PIC

4) Various state-omned vehicles that can be equipped with plug-in radios. 
GOVERNOR

The Hon. John D. Asheroft (Term ends January 1989)

State Capitol

Jefferson City, Missouri 65101

(314) $751-3222$

\section{EMERGENCY SERVICES}

The State Emergency Management Agency in the Office of the Adjutant General is the initial contact point for emergency organizations throughout the state. The agency coordinates both the Missouri Nuclear Emergency Assistance Plan and the Missouri Nuclear Emergency Team. The team comprises members from the agency; the Bureau of Radiological Health; the University of Missouri; and local organizations, academic institutions and private industry.

Richard D. Ross, Director

State Emergency Management Agency

1717 Industrial Drive

P.0. Box 116

Jefferson City, Missouri 65102

(314) $751-9500$

(314)751-2748 (24 hour)

\section{HEAL TH SERVICES}

The Department of Health is the lead agency for radiation control. A 1985 law directed the department to develop a radiation data management program and radiological laboratory capabilities. In addition, the law directed it, in coordination with other agencies, to respond to radtological emergencies.

Robert G. Harmon, M.D., M.P.H.

Director, Department of Health

1738 East Elm

P.0. Box 570

Jefferson City, Missouri 65102

(314) $751-6001$

DESIGNEE FOR ADVANCE NOTIFICATION OF SHIPMENTS

Richard D. Ross, Director

State Emergency Management Agency

1717 Industrial Drive

P.0. Box 116

Jefferson City, Missouri 65102

(314) $751-9500$ 
RADIOLOGICAL EMERGENCY ASSISTANCE CONTACTS

Missouri Department of Health

Division of Enviromental Health and

$(314) 751-6083$

Epidemiology

1730 East Elm, P.0. Box 570

Jefferson City, Missouri 65102

Emergency Team Members

Name Title

Miller, Kenneth V. Chief

NeNutt, Gary W. Radiological Health Analyst

Cope, Reggie D. Radiological Health Analyst

Tschetter, Michael J. Radiological Health Analyst

Diaz, Leticia R. Radiological Health Analyst

Dyer, Margie L. Radiological Health Analyst

LABORATORY AND ANALYTICAL PROGRAMS

Type of Sample Type of Analysis

Major Equipment

Environmental

Media

(air, water,

Gamma (MCA)

Canberra Series 90

soil, etc.)

Alpha, Beta

Tennelec Model 5100

Beta liquid scintillation

Packard Model 2250 CA

Alpha spectrometer

Canberra Model 7404 
NORTH CAROLINA

GOVERNOR

The Hon. James G. Martin (Term ends January 1989)

State Capitol

Raleigh, North Carolina 27611

(919) $733-5811$

\section{EMERGENCY SERVICES}

The Department of Crime Control and Public Safety has primary responsibility for emergency operations preparation and conduct. When an event involves the participation of more than one state agency, the secretary of the department can designate a lead agency and allocate the necessary state resources.

The Division of Emergency Management activates the Emergency Operations Center and the State Emergency Response Team as directed by the department. Its Area Emergency Management Coordinators provide liaison with federal, state and local officials regarding communication, damage assessment and response coordination.

Joseph Myers, Director

Division of Emergency Management

Department of Crime Control and Public Safety

116 West Jones Street

Raleigh, North Carolina 27611

(919) 733-3867

\section{HEALTH SERVICES}

The Department of Human Resources administers the Agreement State Program under the rules and regulations of a governor-appointed Radiation Protection Cammission. It is designated as the lead agency for radiological materials emergency response and radiation protection. Technical response is provided through its Division of Facility Services.

I.0. Wilkerson, Jr., Director

Division of Facility Services

Department of Human Resources

701 Barbour Drive

Raleigh, North Carolina 27603-2008

(919) $733-4283$ 
DESIGNEE FOR ADVANCE NOTIFICATION OF SHIPMENTS

Cap. Walter K. Chapman

Director, Administrative Services

North Carolina Highway Patrol Headquarters

P.0. Box 27687

Raleigh, North Carolina 26711

(919) 733-7952

RADIOLOGICAL EMERGENCY ASSISTANCE CONTACTS

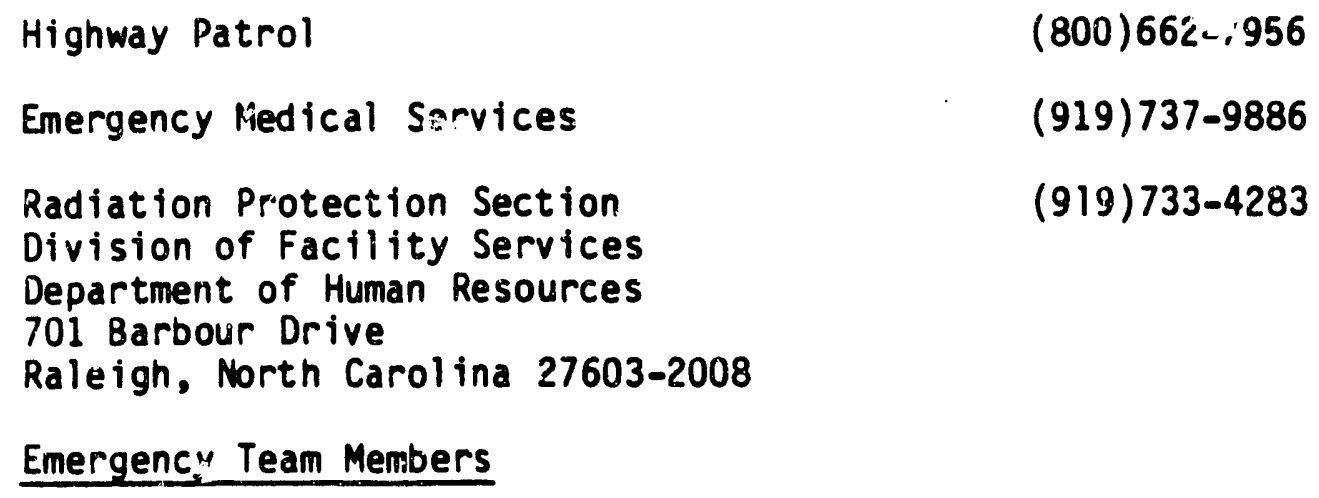


Crocker, William F., Jr.

Hance, David A.

Dusenbury, Bernard Daly, Jr.

Mabry, Allen M.

Howel1, David C.

Haden, J. Robin

Lee, Willie J.

LABORATORY AND ANALYTICAL PROGRAMS

MCA

1. One (1) computer based MCA system (ND-9900) for data analysis, data management and file storage (including MicrovaX II CPU with 5MB memory; 71MB hard disk; dual floppy drive; TK50 streaming tape; 8 user capability; Fortran; Basic and DECgraph).

2. One (1) computer based MCA (ND-6620) for data analysis, dita management and results storage ( $224 \mathrm{~K}$ bytes memory, 2 dual hard disks, Fortran \& Basic interpreters, 4 serial ports for terminal communication and data transfer).

3. One (1) Nuclear Data ND-66 multi-channel Analyzer/Terminal system for data acGuisition and as a remote video terminal for data analysis when connected to the ND-6620 or the ND-9900 system through telephone communication.

4. One (1) Quantum Technology MCA software card and nuclear identification software used in an IBM PC XT for gamma spectroscopy.

\section{Detectors}

1. Two (2) PGT lithium drifted germanium Ge(Li) detectors for gamma spectroscopy [Efficiency: 18.2\% ( $\$ 1)$ and 15\% ("2); FWH: $1.95 \mathrm{KeV}(\$ 1)$ and $1.8 \mathrm{KeV}$ $(\# 2)$ ].

2. One (1) PGT portable intrinsic germanium detector with a liquid nitrogen autofill system ( $13 \%$ efficiency, $1.85 \mathrm{KeV}$ resolution at $1.33 \mathrm{MeV}$ ).

3. One (1) intrinsic germanium detector (N-type; 35\% efficiency, $2.0 \mathrm{KeV}$ resolution and $1.33 \mathrm{MeV}$ ).

4. One (1) Harshaw $4 \times 4$ inch $\mathrm{NaI}$ (T1) scintillation crystal coupled to a PM tube for gamma spectroscopy data acquisition.

5. One (1) EG\&G Ortec (BR-025-450-100) silicon surface barrier detector with electronics and vacuum chamber and vacuum pump for alpha spectroscopy. 
6. One (1) Quantum Technology $3 \times 3$ inch NaI (T1) scintillation crystal for gamma spectroscopy.

7. One (1) Harshaw low background alpha/beta/gamma manual Phoswich Counting System utilizing $\mathrm{CaF}_{2}$ and $\mathrm{NaI}$ detectors.

\section{Computers and Accessories}

1. One (1) MicrovaX II CPU with 5MB memory and 71MB hard disk (this is the same MCA system as described above).

2. One (1) Toshiba T3100 portable computer with 640KB RAM and 10MB fixed disk.

3. Two (2) IBM PC XTs with 640 KB RAM and 20 MB fixed disks.

4. Two (20 TRS-80 portable computers.

5. One (1) programmable calculator (TI-59) with printer (PC-100A).

6. Two (2) Digital DECwriters and a Datec 212 modem for data reception through telephone communication from a remote microcomputer.

7. One (1) Digital LA210 letter printer.

\section{TLD Readers}

1. One (1) Panasonic UD-702E manual TLD reader with 400 environmental dosimeters and 75 personnel dosimeters.

2. One (1) manual TLD reader (Teledyne Isotope Model 8310) with $150 \mathrm{CaSO}_{4}$ (Dy) dosimeters.

3. One (1) Eberline TLD Reader (Model TLR-5).

\section{Radon Measurement Capability}

1. One (1) Pylon AB-5 Portable Radiation Monitor with PPT-1 printer and one (1) Lucas Cell Adapter LCA-2; four (4) Model 300 cells; one (1) Model 3150 calibration standard; one (1) RN-190-47 Radon Daughter Standard; one (1) AEP-47 Alpha Detector Assay; one (1) RFA-47 reverse flow adapter.

2. One (1) Pylon WG-1001 vacuum water degassing system for radon in water measurement.

3. One (1) charcoal canister measurement system using the $3 \times 3$ inch NaI crystal system as described in "Detectors" above.

4. Charcoal canisters (capability to fabricate charcoal canisters for radon measurement).

Communication Equipment

1. One (1) SSB Transceiver, Scientific Radio System (Model SR-206-MS-1).

2. Four (4) Motorola 32 Channel Radios (Syntor X-9000). 
3. Five (5) Hand-held Portable Transceivers (Radios) (Revco Model RPNSL44HC).

4. One (1) Bearcat Scanner (Model BC-250).

5. One (1) Portable Celiular Telephone.

Air Samplers and Accessories

1. Five (5) battery powered portable air samplers.

2. Five (5) high-volume portable air samplers.

3. Three (3) portable electric generators.

4. One (1) Sierra-Misco Weather Station (Model 1045).

5. One (1) Sierra-Misco Wind Direction Control System.

In-House Counting Systems

1. Three (3) Tennelec LB-5100 series automatic low background Alpha/Beta counting systems. Each has an automatic sample changer for 50 samples.

2. One (1) Searle Analytic Isocap 300, Liquid Scintillation System of Model 6868 with automatic sample changer for 300 samples.

3. Two (2) in-house constructed Radon Flask counting assembly and radon gas emanation systems for determining radon and Ra-226 concentrations in water. Systems utilize $150 \mathrm{ml}$ bubblers of 2 -inch diameter Lucas cells.

Field Counting Instruments

1. One (1) Reuter-Stokes RSS-111 high pressure ionization chamber for gross gamma measurement.

2. Two (2) Ludlum Model 2218 Dual Stabilized Analyzers with 1/2" by 2" (dia) $\mathrm{Nal}$ crystals for field radiolodine measurement with silver zeolite radioiodine cartridge.

3. Two (2) Eberline Portable Rate Meters (Model PRS-1 [Rascal]) with hand-held probes; sample holders; crystals; and special carrying case.

4. Five (5) Ludlum Model 19 Micro R Meters for gross gamma radiation measurement.

\section{Survey Instruments}

1. Five (5) Eberline Survey Meters (Model PAC-4G-3).

2. Two (2) Eberl ine Survey Meters (Model E-520).

3. Two (2) NARDA Electromagnetic Radiation Monitors (Model 8110).

4. Two (2) Eberline Survey Meters (Model E-130-G). 
5. Four (4) Victoreen Portable Survey Meters (Model 470A).

6. Six (6) X-ray survey Meters MFG. by MDH (Model $1015 \mathrm{C}$ with ion chambers).

7. Three (3) Eberline Monitors; thin end window GM up to $50 \mathrm{mR} / \mathrm{hr}$ (Model 1A).

8. Five (5) Ludlum Survey Meters (Model 14C).

9. Two (2) Ludlum Survey Meters (Model 2).

10. One (1) Ludlum Survey Meter (Model 6).

11. One (1) Dosimeter Mini; thin end window GM up to $500 \mathrm{mR} / \mathrm{hr}$ (Model Conrad II).

12. Two (2) NERO, Non-Evasive Radiation Output monitors. 


\section{OKLAHOMA}

GOVERNOR

The Hon. Henry Bellmon (Term ends January 1991)

State Capitol

Okl ahoma City, Oklahoma 73105

(405) $521-2342$

\section{EMERGENCY SERVICES}

The director of Oklahoma Civil Defense, acting on behalf of the governor, directs and coordinates the interagency and volunteer emergency services during a disaster. The state is divided into four civil defense districts, with headquarters in each.

Woodrow Goins, Acting Director

Oklahoma Civil Defense

P.0. Box 53365

OKlahoma City, Oklahoma 73152

(405) $521-2481$

\section{HEALTH SERVICES}

The Department of Health implements policies developed by the State Board of Health. The Board receives guidance from a Board-appointed Radiation Advisory Committee in matters concerning radiation protection. Radiological emergency response is under the control of the Chief, Radiation and Special Hazards Service, Department of Health.

Joan K. Leavitt, M.D.

Commissioner

State Department of Health

P.0. Box 53551

Oklahoma City, Oklahoma 73152

(405) 271-4200

\section{DESIGNEE FOR ADVANCE NOTIFICATION OF SHIPMENTS}

Clent Dedek

Commissioner of Public Safety

Oklahoma Department of Public Safety

3600 N. King Avenue

P.0. Box 11415

Oklahoma City, Oklahoma 73136-0415

(405) 424-4011 
RADIOLOGICAL EMERGENCY ASSISTANCE TEAM CONTACTS

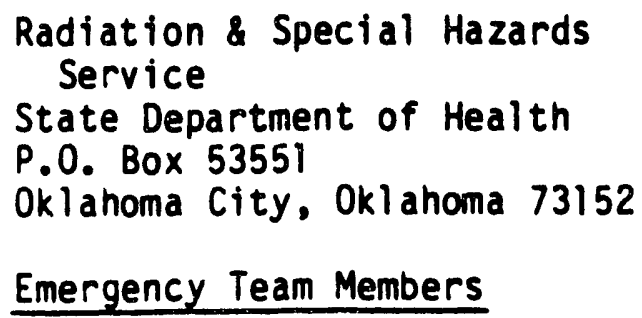

LABORATORY AND ANALYTICAL PROGRAMS

\begin{tabular}{lll} 
Type of Sample & Type of Analysis & Major Equipment \\
\hline Air & Gross Beta & $\begin{array}{l}\text { One } 3 \times 3 \text { NAI crystal with } 8196 \\
\text { channel analyzer and low back- } \\
\text { ground steel shield. }\end{array}$ \\
Wmbient Gamma & TLD & One GM counter for HI-Vol fil- \\
& Gamma Spectrum & ters \\
Gross Beta & Urans Alpha & One GeLi detector with 8196 \\
Radium & channel analyzer with low back- \\
& ground steel shield and compu- \\
& terized analysis capability. \\
& & Two thin window proportional \\
& counters with 100 sample capa- \\
& city sampis cisarger.
\end{tabular}

Four (4) Vehicle-mounted gamma surveillance systems (WAGS)

Six (6) Hi-Vol air samplers 


\section{SOUTH CAROLINA}

\section{GOVERNOR}

The Hon. Carroll Campbell (Term ends January 1991)

State House

P.0. Box 11369

Columbia, South Carolina 29211

(803) 734-9818

\section{EMERGENCY SERVICES}

The Emergency Preparedness Division, Office of the Adjutant General, coordinates the disaster training and response activities of the state and local governments. In the event of an emergency, the division may establish a state emergency operations center and/or a forward emergency operations center in the threatened area.

Raymond L. Brown, Director

Emergency Preparedness Division

Office of the Adjutant General

1429 Senate Street

Columbia, South Carolina 29201

(803)734-8020

\section{HEALTH SERVICES}

The Department of Health and Environmental Control administers the Agreement State Program. The department is advised on radiation control issues by a governor-appointed Technical Advisory Radiation Control Council.

For response to radiological incidents, the department trains and maintains an Emergency Radiological Assistance Team. Its Bureau of Radiological Health is prepared to provide monitoring, protective action guidance, exposure control and advice on decontamination and disposal.

Michael D. Jarrett

Commissioner, Department of Health and Environmental Control

2600 Bull Street

Columbia, South Carolina 29201

(803) $734-4880$

DESIGNEE FOR ADVANCE NOTIFICATION OF SHIPMENTS

Heyward Shealy

Chief, Bureau of Radiological Health

South Carolina Department of Health and Environmental Control

2600 Bull Street

Columbia, South Carolina 29201

(803) $734-4700$ 
RADIOLOGICAL EMERGENCY ASSISTANCE CONTACTS

\section{State Patrol}

Bureau of Radiological Health

South Carolina Department of

Health and Environmental Control

2600 Bull Street

Columbia, South Carolina 29201

Emergency Team Members

Title

Shealy, Heyward G.

Chief, Bureau of Radiological Health

Dobbs, Lynn B.

Program Management Specialist

MeGlohorn, Danny

Director, Division of Electronic Products

Autry, Virgil

Director, Division of Radioactive Materials Licensing

Bivens, C. Nolan

Director, Division of Radiological Environmental Surveillance

Craft, Bert

Chemist

Patterson, Beverly

Health Physicist

Threatt, Sandra

Health Physicist

O'Kelley, Pearce

Heal th Physicist

LABORATORY AND ANALYTICAL PROGRAMS

Type of Sample Type of Analysis

$$
\text { Air }
$$

Direct Exposure

Milk

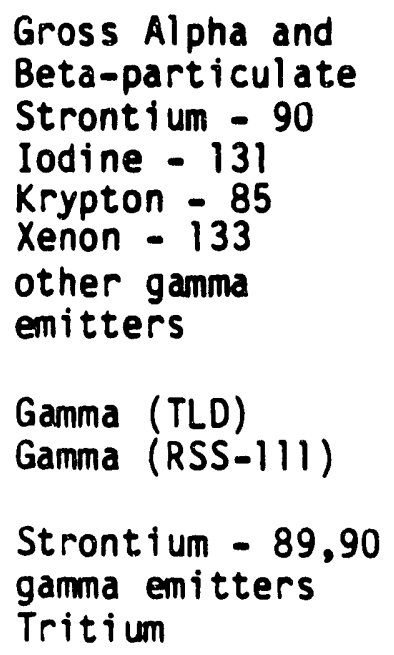

Major Equipment

Nuclear Data 66 System, multichannel analyzer-computer with 3 GeLi detectors, printout and live display.

Eberline TLR-5 Thermoluminescent Dosimeter Reader (LiF TLDs used).

Canberra 8110 Multichannel Analyzer System with $\mathrm{NaI}(3 \times 3)$. Tennelec LB-5100 Beta Analyzer, Automatic System. 
Silt, Soil
and Vegetation

Water
Gross Alpha

Gross Beta

gamma emitters

Gross Alpha

Gross Beta

Tritium

Strontium - 89,90

Cobalt - 58, 60

Cesium - 137

lodine - 129,131

Other yamma emitters

Plutonium - 238,239
Packard 1550 LL Liquid Scintillation System with printout.

Harshaw 2000B Thermoluminescent Reader (LiF TLDs used).

Nuclear Date Model 66 Analyzer with 8192 Channels. Compaq Computer interface. Downlooker GeLi Detector.

Portable Micro R Meters, Pic 6A, E520 with pancake and HP270s.

\section{Emergency Vehicles}

- Mobile Radiological Laboratory (Superior 25' Motor Home), mobile radio, decontamination capability, air samplers, radiation monitoring, dress out packs and field analysis instrumentation.

o Boat equipped with electro-fish shocking equipment.

- Eight vehicles equipped with VHF transceivers; six hand-held or portable transceivers; portable base station. 


\section{TENNESSEE}

\section{GOVERNOR}

The Hon. Ned Ray McWherter (Term ends January 1991)

State Capitol

Nashville, Tennessee 37219

(615) $741-2001$

\section{EMERGENCY SERVICES}

The Tennessee Emergency Management Agency (TEMA), within the Department of Military, is the responsible agency for the development of state emergency plans and procedures. By Executive Order, TEMA is the responstble agency for coordinating state response to all emergencies, including peacetime radiological accidents. TEMA also provides an Emergency Operation Center that is operational twenty-four hours a day. TEMA provides radtological instrumentation to state and local government agencies for use in the detection of radiation. TEMA coordinates and conducts radiological training for state and local radiological emergency responders.

Lacy E. Suiter, Director

Tennessee Emergency Management Agency

Stae Emergency Operation Center

3041 Sidco Drive

Nashville, Tennessee 37204-1502

(615) 252-3300

\section{HEALTH SERVICES}

The Department of Health and Environment administers the state's Agreement State Program. In support of the Tennessee Emergency Management Agency, the department provides radiological monitoring, training guidance, protective action advice and decontamination assistance. The department's Division of Radiological Health is responsible for training and equipping Radiological Monitoring Teams, which are part of the State Radiological Response Team. It al so provides radiological accident assessments.

James E. Hord, Commissioner

Department of Health and Environment

344 Cordell Hull Building

Nashville, Tennessee 37217-5402 
DESIGNEE FOR ADVANCE NOTIFICATION OF SHIPMENTS

John White

Assistant Deputy Director

Tennessee Emergency Management Agency

State Emergency Operations Center

3041 Sidco Drive

Nashville, Tennessee 37204

(615) 252-3300

RADIOLOGICAL EMERGENCY ASSISTANCE CONTACTS

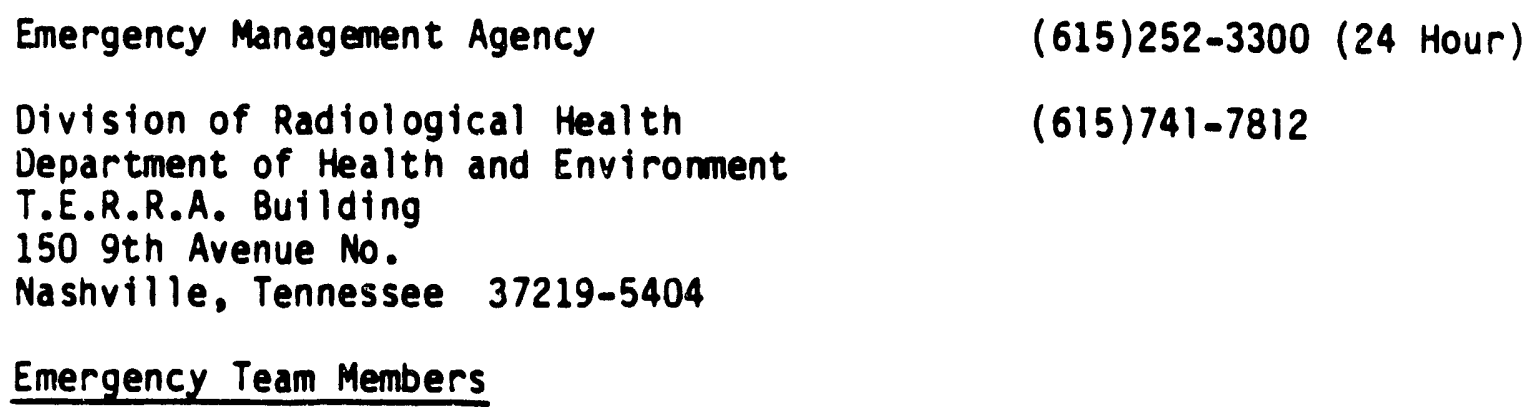


LABORATORY AND ANALYTICAL PROGRAMS

\begin{tabular}{lll} 
Type of Sample & Type of Analysis & Major Equipment \\
\hline Air & Gross Alpha-Beta & TLD (Harshaw TLD Reader) \\
Strontium - 89,90 & \\
Gamma Spectroscopy & Strontium - 89, 90 \\
& Gamma Spectroscopy \\
I-131 Cartridges & Gamma Spectroscopy \\
Milk & Iodine - 131 Chemical \\
& Strontium - 89, 90 \\
& Gamma Spectroscopy \\
Silt, Soil, & Gross Alpha-Beta \\
Vegetation & Gamma Spectroscopy \\
Water & Gamma Spectroscopy \\
& Gross Alpha-Beta \\
& Strontium - 89, 90 \\
& Tritium
\end{tabular}


GOVERNOR

The Hon. Bill Clements (Term ends January 1991)

State Capitol

Austin, Texas 78711

(512) $475-4101$

\section{EMERGENCY SERVICES}

The Division of Emergency Management prepares, maintains and coordinates the state's comprehensive emergency plan. A Disaster Emergency Funding Board maintains a disaster contingency fund. The governor, lieutenant governor and the directors of the State Board of Insurance, the Department of Human Resources and the Division of Emergency Management are members.

The division provides the emergency response functions that are not available through other state agencies. These include shelter planning and promotion, crisis relocation planning, continuity of government programs, resources management, economic stabilization plans, emergency public information activities, emergency management training, hazard mitigation and recovery and rehabilitation activities.

Robert A. Lansford, Coordinator

Division of Emergency Management

Department of Public Safety

P.0. Box 4087

Aust in, Texas 78733

(512) $465-2000$

\section{HEALTH SERVICES}

Texas' radiation safety statute designates the Department of Health as the radiation control agency. The Bureau of Radiation Control within the agency administers the Agreement State Program. In the event of a radiological incident, the bureau is responsible for detection, measurement and clean-up of materials that are released to the environment. It also provides an assessment of the incident as the basis for the assignment of protective responses.

Robert Bernstein, M.D.

Commissioner

Department of Health

1100 West 49th Street

Austin, Texas 78756

(512)458-7375 
DESIGNEE FOR ADVANCE NOTIFICATION OF SHIPMENTS*

Robert Bernstein, M.D. (10 CFR Part 71)

Commissioner

Department of Health

1100 West 49th Street

Austin, Texas 78756

(512) 458-7375

Col. Leo Gossett (10 CFR Part 73)

Director

Texas Department of Public Safety

5805 North Lamar Blvd.

Austin, Texas 78752

(512) $465-2000$

* Texas is the only SSEB member state in which two separate agencies are designated to receive prenotification for the two types of shipments.

RADIOLOGICAL EMERGENCY ASSISTANCE CONTACTS

(Street Address)

Bureau of Radiation Control

1212 East Anderson Lane

(US-183, East)

Austin, Texas 78752

(Mailing Address)

Bureau of Radiation Control

Texas Department of Health

1100 W. 49th Street

Austin, Texas 78756-3189

Division of Emergency Management

(512)835-7000 (8AM - 5PM)

(512)458-7460 (24 Hour)

(512) 465-2000

Ext. 2138 (8AM - 5PM)

Ext.2277 (24 Hour)

Emergency Team Members

Name

Title

Lacker, David K.

Chief, Bureau of Radiation Control

Bailey, Edgar D.

Director, Division of Licensing, Registration and Standards

Ratliff, Richard A. Director, Division of Compliance \& Inspection

Free, Robert E.

Administrator, Emergency Response \& Investigation Branch, Division of Compliance \& Inspection 
Born, Clarence L.

Manager, Emergency Response Planning Program

Thiel, Joseph F.

Emergency Planner

Emergency Team Composition

The Bureau of Radiation Control's Radiological Emergency Response Team includes, but is not limited to, the following manpower and skills. These are nomally divided into two 12-hour shifts, but can be activated in other combinations if required.

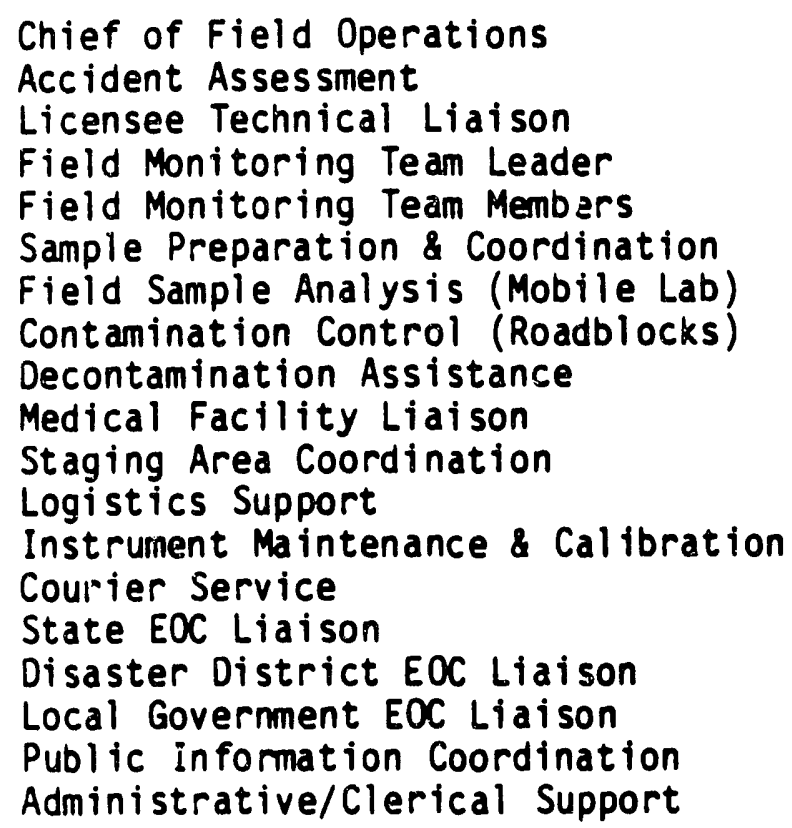

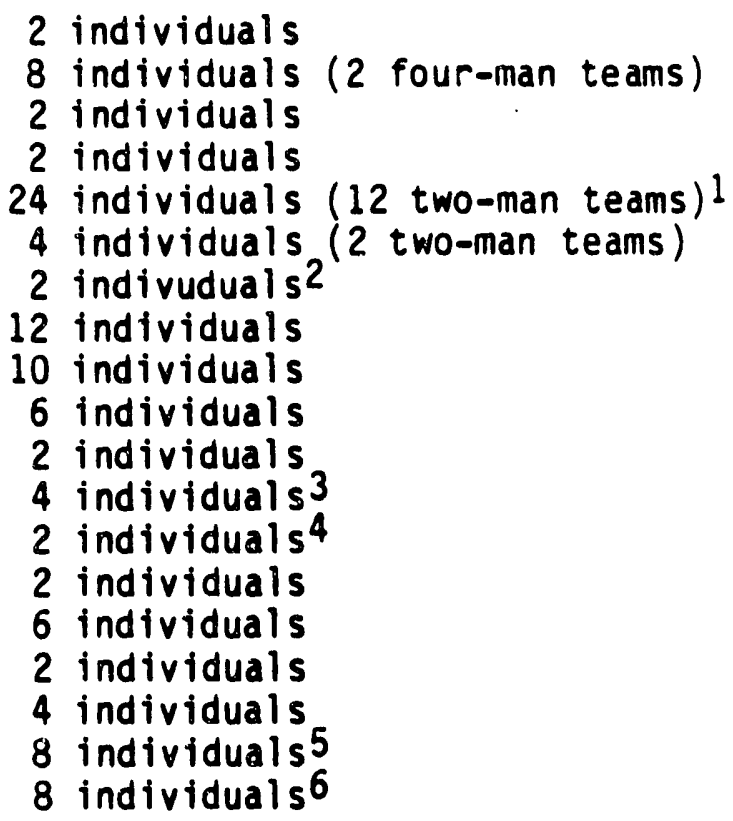

Includes 12 individuals from the Texas Department of Public Safety.

2These individuals are from the Department of Health's Bureau of Laboratories. 3 Includes two individuals assigned to 12-hour shifts in the Austin office. 4 These individuals are from the Department of Health's Bureau of Emergency Management.

5 Includes two individuals from the Texas Low-Level Radioactive Waste Disposal Authority.

6 Includes two individuals assigned to 12-hour shifts as switchboard operators in the Bureau's Austin office.

\section{Detection, Measurement and Evaluation Systems}

\section{Fixed Laboratory Facility}

The Bureau of Laboratories, Texas Department of Health, has in its headquarters laboratory the following equipment:

1 Canberra Jupiter Sertes 85 Multichannel Analyzer

1 Canberra Series 8180 Multichannel Analyzer

1 Canberra Series 8100 Multichannel Analyzer

2 Automatic Sample Changers

3 High Purity ( $>30 \%$ ) Germanium Detectors (2 p-type, 1 n-type) 
7 Proportional Systems

5 Ludlum Model 2000 Scalers with scintillation detectors

1 Liquid Scintillation System

\section{Mobile Laboratory}

The Bureau's mobile analysis laboratory is contained within a 45'electronics van-type semi-trailor. Using power supplied by the truck-mounted $15 \mathrm{kw}$ gennerator, or commercial 220v/150-200 amp single-phase power, samples can rapidiy be processed in one of three onboard systems. The configuration includes a Harshaw TASC-12 proportional counter capable of simultaneous and separate detection of alpha, beta and ganma; a p-type high purity ( $>30 \%$ ) gemanium spectroscopy system; a $4 " \times 4$ " Sodium Iodide unit; and a DEC $\Pi / 24$ computer system with dose projection software, computer graphics terminals, printers and modems.

\section{Emergency Response Vehicle}

The Bureau's emergency response vehicle consists of a large modular ambulance-type vehicle equipped for incident response. Power can be supplied by a truck-mounted $6.5 \mathrm{kw}$ generator or obtained from commercial distribution lines. Identification is performed using a Harshaw TASC-12 proportional counter capable of simultaneous and separate detection of alpha, beta and gamma, and an Ortec Model 7150 multichannel analyzer with a $2 " \times 2 "$ Sodium Iodide detector.

\section{Miscellaneous Equipment}

In addition to the equipment listed for the laboratory and the mobile units, the Bureau of Radiation Control has the following miscellaneous equipment available for incident response:

15 power inverters (12vdc to $115 \mathrm{vac}, 60 \mathrm{~Hz}$ )

15 high volume air samplers with silver zeolite cartridges and particulate filters

12 Portable Multichannel Analyzers

98 Ludl um 14-C survey meters with:

69 Ludlum model 44-6 Thin Wall Gamma Probes

69 Ludl um model 44-2 High Energy Gamma Scintillators

30 Ludlum model 44-3 Low Energy Gamma Scintillators

55 Ludlum model 43-2 Alpha Scintillators

6 Ludlum model 44-40 Shielded Pancake Probes

24 Ludlum model 44-9 Pancake Probes

6 Ludlum model 44-7 End Window Geiger-Muller Probes

c 200 0-200mR Self-Reading Pocket Dosimeters

C 200 0-20R Self-Reading Pocket Dosimeters

250 Emergency Response Team identification badges with (2 each) TLD permanent dosimetry chips incorporated

30 Scott model 652 full facepiece respirators with (2 each) combination HEPA filters \& charcoal cartridges (Scott model 642TEDAR)

12 hand-held 2-watt radios

2 (25-watt) base radios (porti-mobile)

1 (40-watt) repeater (installed in mobile laboratory) 


\section{VIRGINIA}

GOVERNOR

The Hon. Gerald L. Baliles (Term ends January 1990)

State Capitol

Richmond, Virginia 23219

(804)786-2211

\section{EMERGENCY SERVICES}

The Department of Emergency Services administers the emergency operations plan. The office is also charged with monitoring the transportation of radioactive materials. During an emergency, the governor is the director of emergency services and has full control over the office.

A.E. Slayton, Jr., Coordinator

Department of Emergency Services

310 Turner Road

Richmond, Virginia 23225

(804)674-2497

\section{HEALTH SERVICES}

The Department of Health implements prograns for the State Board of Health, which is the lead agency for radiation safety. The department maintains a Radiological Emergency Response Team for assessment and response. It also provides guidance on protective actions, requests specific assistance from other agencies, establishes exposure control, coordinates the use of medical facilities and identifies controlled areas around the accident site.

C.M.G. Buttery, M.D., Commissioner

Department of Health

109 Governor Street

Richmond, Virginia 23219

(804) 786-3561

DESIGNEE FOR ADVANCE NOTIFICATION OF SHIPMENTS

Michael M. Cline

Director of Operations

Virginia Department of Emergency Services

310 Turner Road

Richmond, Virginia 23225

(804)674-2400 
RADIOLOGICAL EMERGENCY ASSISTANCE CONTACTS

Department of Health

$(804) 786-5932$

Bureau of Radiological Health

109 Governor Street

Richmond, Virginia 23219

Emergency Team Members

Name

Vacant

Schrider, Carolyn

Stone, Thomas $W$.

Conway, Richard F.

Gonsoulin, Robert

Gorisch, Manfred L.

dekraft, James $A$.

Foldesi, Leslie P.

Fuller, Michael L.
Title

Supervisor, Bureau of Radiological Health

Radiation Safety Specialist

Radiation Safety Specialist

Radiation Safety Specialist

Radiation Safety Specialist

Radiation Safety Specialist

Radiation Safety Specialist

Radiation Safety Specialist

Radiation Safety Specialist

LABORATORY AND ANALYTICAL PROGRAMS

Type of Sample Type of Analysis

Major Equipment

\begin{tabular}{|c|c|}
\hline Air Particulate & $\begin{array}{l}\text { Gross Beta } \\
\text { Gamma Spectrum }\end{array}$ \\
\hline Charcoal Filter & Gamma Spectrum \\
\hline Milk & $\begin{array}{l}\text { Gamma Spectrum } \\
\text { Strontium - } 89 \& 90\end{array}$ \\
\hline $\begin{array}{l}\text { Vegetation, soil, } \\
\text { dirt, fish }\end{array}$ & $\begin{array}{l}\text { Gross Beta } \\
\text { Gamma Spectrum }\end{array}$ \\
\hline Vater & $\begin{array}{l}\text { Gross Alpha } \\
\text { Gross Beta } \\
\text { Radium - } 226 \& 228 \\
\text { Strontium }-89 \& 90 \\
\text { Gamma Spectrum } \\
\text { Uranium }\end{array}$ \\
\hline
\end{tabular}

Tracon Northern TN-1700 with 4" $\times 4$ " no. 1 (T2) detector.

Tennelec LB5100-Serie 1 proportional counter.

Tennelec LB5100-Series 2 proportional counter.

Randam SC-5 Scintillation counter.

Tracon Northern TN-1700 with GeLi detector

Canberra Series 90 with GeLi detector MCA. 


\section{WEST VIRGINIA}

GOVERNOR

The Hon. Arch A. Moore, Jr. (Term ends January 1989)

State Capitol

Charleston, West Virginia 25305

(304) 348-2000

\section{EMERGENCY SERVICES}

The Office of Emergency Services carries out the emergency services program by coordinating the response activities of all other state organizations. The office supports the radiological protection program by providing communications and office facilities, training and exercises and drills for state agency responders. The office includes the State Radiological Officer, the Radiological Maintenance officer and radiological maintenance technicians and support staff for the radiological protection progran.

Bill R. Jopling, Deputy Director

Office of Emergency Services

State Capitol, Room EB-80

Charleston, West Virginia 25305

(304)348-5380

\section{HEALTH SERVICES}

The Department of Health is responsible for enforcing a 1980 state law that permits the storage and disposal of radioactive waste generated in West Virginia by medical, institutional and industrial activities. The department's Industrial Hygiene Division responds to all peacetime radiological incidents, providing personnel and equipinent for the state Radiological Response Team.

David K. Heydinger, M.D., Director

Department of Health

1800 East Washington Street

Charleston, West Virginia 25305

(304) 348-2971

DESIGNEE FOR ADVANCE NOTIFICATION OF SHIPMENTS

Col. W.F. Donohoe

Superintendent

Department of Public Safety

725 Jefferson Road

South Charleston, West Virginia 25309

(304)746-2111 
RADIOLOGICAL EMERGENCY ASSISTANCE CONTACTS

Industrial Hygiene Division

Department of Health

151 11th Avenue

South Charleston, WV 25305

(304)348-3526, 3427 (Business

hours)

(304)348-0691 (Emergency contact

only and during

business hours)

Emergency Team Members

Name

Title

Aaroe, William $\mathrm{H}$.

Director, Industrial Hygiene Division

De Bord, B. L.

Radiological Health Specialist, Radiological Health Section

LABORATORY AND ANALYTICAL PROGRAMS

Type of Sample Type of Analysis

Major Equipment

Any applicable Gross Alpha

Harshaw LBS

Gross Beta

Ganma Spectroscopy

ND 66

(call to check if

operational)

Victoreen (Bulb) Dosimetry TLD 

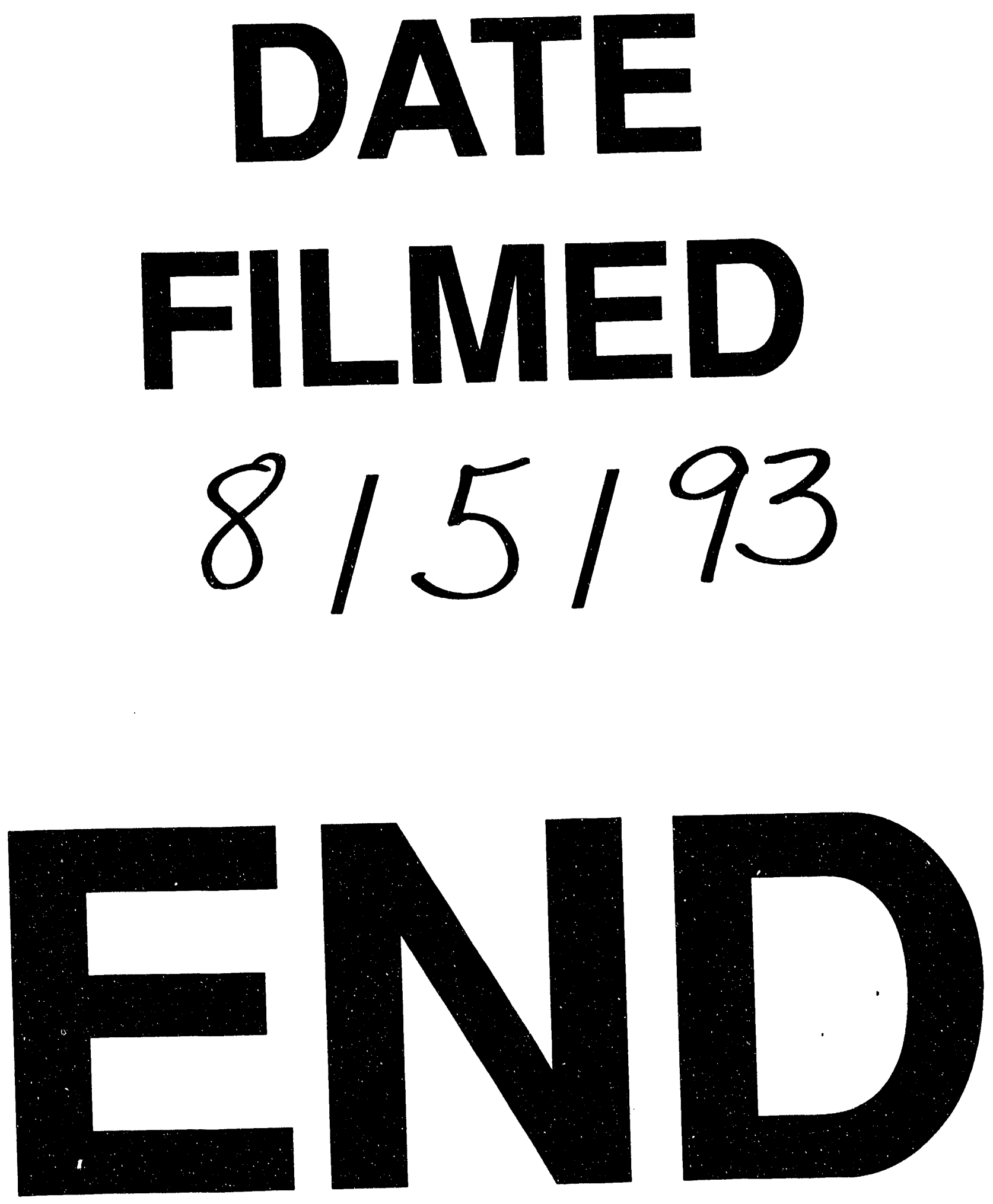
